\title{
Diversity and Abundance of Pest Insects Associated with Solanum aethiopicum Linnaeus, 1756 (Solanaceae) in Balessing (West-Cameroon)
}

\author{
Boris Fouelifack-Nintidem, Jeanne Aggripine Yetchom-Fondjo, Sedrick Junior Tsekane, \\ Babell Ngamaleu-Siewe, Edith Laure Kenne, Miric Biawa-Kagmegni, Patrick Steve Tuekam-Kowa, \\ Abdel Kayoum Yomon, Rossi Merlin Kentsop-Tsafong, Armel Moise Dim-Mbianda, Martin Kenne*
}

Department of the Biology and Physiology of Animal Organisms, University of Douala, Douala, Cameroon

\section{Email address:}

fouelifacknintidemboris@yahoo.fr (B. Fouelifack-Nintidem), jayetchomfondjo@gmail.com (J. A. Yetchom-Fondjo),

stsekane@yahoo.com (S. J. Tsekane), babellngamaleu@yahoo.fr (B. Ngamaleu-Siewe), edithlaure.kenne@yahoo.fr (E. L. Kenne),

biawamiric@gmail.com (M. Biawa-Kadmegni), tukopast@gmail.com (P. S. Tuekam Kowa), abdelkayoumyomon@yahoo.fr (A. K. Yomon), kentsafrosmer90@yahoo.com (R. M. Kentsop-Tsafong), dimarmel2016@yahoo.com (A. M. Dim-Mbianda), medoum68@yahoo.fr (M. Kenne), martin.kenne@univ-douala.cm (M. Kenne)

${ }^{*}$ Corresponding author

\section{To cite this article:}

Boris Fouelifack-Nintidem, Jeanne Aggripine Yetchom-Fondjo, Sedrick Junior Tsekane, Babell Ngamaleu-Siewe, Edith Laure Kenne, Miric Biawa-Kagmegni, Patrick Steve Tuekam-Kowa, Abdel Kayoum Yomon, Rossi Merlin Kentsop-Tsafong, Armel Moise Dim-Mbianda, Martin Kenne. Diversity and Abundance of Pest Insects Associated with Solanum aethiopicum Linnaeus, 1756 (Solanaceae) in Balessing (WestCameroon). American Journal of Entomology. Vol. 5, No. 3, 2021, pp. 70-91. doi: 10.11648/j.aje.20210503.14

Received: August 24, 2021; Accepted: September 6, 2021; Published: September 14, 2021

\begin{abstract}
Despite chemical treatments, all development stages of Solanum aethiopicum Linnaeus, 1756 plants are damaged in the field by insects in Balessing locality (West-Cameroon). During ecological surveys conducted from July to October 2020 in 11 plots presenting four development stages: seedlings (St1), fruit setting plants (St2), flowering phase plants (St3), and fruiting phase plants (St4). Insects active on stems, leaves, flowers and fruits, were captured, identified and the community structure was characterized. Abundance of each species and the part of the plant attacked were noted. Specimens were stored in vials containing $70^{\circ}$ alcohol while immature insects were reared in the laboratory till the adult emergence. A total of 155 specimens collected in the field belonged to four orders, 13 families and 22 species. Lepidoptera and Hemiptera were most abundant $(38.7 \%$ and $34.8 \%$ of the total collection respectively). Coleoptera and Orthoptera were least abundant ( $14.2 \%$ and $12.3 \%$ respectively). In the laboratory rearing, two Lepidoptera emerged from reared caterpillars: the Crambidae (Leucinodes orbonalis Guenee, 1854) and the Noctuidae [Helicoverpa armigera (Hübner, 1808)]. This gives a total of four orders, 14 families, 22 genera and 23 species associated with eggplant plants. In the field, plants were damaged by three borer species (13.0\%) [Phrissotrichum grenieri (Desbrochers, 1875) (Coleoptera, Brentidae), Le. orbonalis (Lepidoptera, Crambidae) and $H$. armigera (Lepidoptera, Noctuidae)], by five phytophagous pest species (21.7\%) [Lagria villosa (Fabricius, 1781) (Coleoptera, Tenebrionidae), Leptoglossus occidentalis Heidemann, 1910 (Hemiptera, Coreidae), Manduca sexta Linnaeus, 1763 (Lepidoptera, Sphingidae), Sphaerocoris annulus (Fabricius, 1775) (Hemiptera, Scutelleridae) and Taphronota ferruginea (Fabricius, 1781) (Orthoptera, Pyrgomorphidae)], three sap-feeding species (13.0\%) [Dysdercus volkeri (Schmidt, 1932) (Hemiptera, Pyrrhocoridae), Edessa rufomarginata (De Geer, 1773) (Hemiptera, Pentatomidae) and Gonocerus acuteangularis (Goeze, 1778) (Hemiptera, Coreidae)] and 12 species of unknown pest-status. We recorded 11 pest species (47.8\% of the total species richness) [six (26.1\%) non-native and five (21.7\%) native species]. Coleoptera presented a high number of species (34.8\%) followed by Hemiptera (30.4\%), Orthoptera (21.7\%) and Lepidoptera (13.0\%). Lepidoptera Crambidae (38.1\%) was the most represented, followed by Hemiptera Pentatomidae (14.1\%), Orthoptera Acrididae (10.2\%), Hemiptera Coreidae and Hemiptera Pyrrhocoridae (7.7\% respectively), Hemiptera Scutelleridae (5.2\%), Coleoptera Tenebrionidae (5.1\%), Coleoptera Chrysomelidae (4.5\%), Orthoptera Pyrgomorphidae (3.9\%) and Coleoptera Brentidae (1.3\%). Three families (Carabidae, Sphingidae and Scarabeidae) were rare $(<1 \%$ of the total collection). Chemicals were not efficient in Balessing, since entomofauna associated with eggplant plants remained diverse and consisted mostly of alien species. The situation calls for
\end{abstract}


more research on the bio-ecology of the recorded pests with further goal of developing sustainable management strategies to reduce yield losses.

Keywords: Solanum aethiopicum, Pest Insects, Biodiversity, Balessing (Cameroon)

\section{Introduction}

Ethiopian eggplant Solanum aethiopicum Linnaeus, 1756 (Solanaceae) is one of the most cultivated and consumed vegetable fruits in the world. It is the second highly consumed vegetable behind Abelmoschus esculentus (L.) Moench, 1794 (Malvales) and is an essential crop for food security [1]. Apart from So. melongena Linnaeus, 1753 (Solanaceae), which is highly cultivated in the tropical and subtropical regions of the world, So. aethiopicum Linnaeus, 1756 and So. macrocarpon Linnaeus. 1771 are also of great importance in sub-Saharan Africa region [2, 3]. The African native So. aethiopicum, is cultivated for fruits and leaves [47]. Fruits are sources of protein, carbohydrates, calcium, potassium, iron, vitamins (A, B and C), phosphorus, sodium, magnesium, fibbers and antioxidants [8-10] which are essential for the good nutrition of man and livestock [11, 12]. Eggplant is the fifth most economically important crop after potato, tomato, pepper, and tobacco [13]. In Africa, eggplant is mainly produced in Mediterranean countries [13]. In Cameroon, the overall production is insufficient to meet the ever-increasing demand in the cities. Causes of low productions are not fully known. Available information from Ethiopia and Cameroon point out the sex and education level of farmers, improved variety, insufficient use of fertilizer, experience of farmers, access to extension, harvesting time, soil conservation, nature of access to land, access to market, access to irrigation schemes, inadequate phytosanitary control, unsuitability of agricultural policies, low soil fertility, the use of infested planting material, high disease and pest infection rates, losses during storage including losses in quality [14-17]. In the field, plants are target of several attacks such as microorganisms (fungi, viruses and bacteria) and metazoan organisms (xylophagous agents). These pestorganisms are responsible of plant diseases [18-20]. They are also damaged by animal species that use them either as a nesting site (case of. insects that drill stems such as larvae of beetles, wasps that can build their nests at the bottom of the leaves), or as a feeding site and thus as a foraging site (termites that rob the plant from the roots, nectarivorous ants and adults of butterflies who feed on sweet liquids secreted by the plant), or both as nesting and feeding site (cases of Hemipterans such as aphids and mealy bugs that pump the plant's sap to exploit proteins and a little sugar and discard the remaining enriched sugar called honeydew) [19, 21-23]. The saliva injected by sap-feeding insects during their food intake can be toxic to the plant as is the case with thrips and aphids $[20,24,25]$. These insects cause direct damage to the eggplant plant throughout its phenological stages and indirectly cause the drastic decreases that affect productivity of the attacked plant $[1,26]$. Several studies on the associated entomofauna with eggplant plants have been conducted worldwide and authors pointed out the negative effect of insect pests [1, 22, 26-30]. Eggplant plants are traditionally cultivated in several areas across Cameroon, but there is no published data on the diversity of insects affecting growth and production. However the control of pest insects is one of the major constraints to be overcome in crop production. Chemical treatments are usually recommended for the eradication of target enemies of crops but their anarchic and uncontrolled use lead to the environmental pollution and the intoxication of farmers [31, 32]. In Balessing, market gardening activities are on the rise, but practiced by young farmers, little educated, unassisted and each having a fairly low income. Physical damages are recorded in plantations. The purpose of this study is to determine the biodiversity of insects and characterize damages on the Ethiopian eggplant plants.

\section{Materials and Methods}

\subsection{Study Sites}

Field observations were conducted in 2020 during the rainy season (July to November) in farms of Ethiopian eggplant located in Balessing (Western region of Cameroon) $\left(5^{\circ} 30^{\prime} 04^{\prime \prime} \mathrm{N}, 10^{\circ} 14^{\prime} 30^{\prime \prime} \mathrm{E}\right.$; altitude: 1,442 m a.s.l) (Figures 1). The locality is situated $21 \mathrm{~km}$ from Dschang (Menoua Department) and $31 \mathrm{~km}$ from Bafoussam (Mifi Department) and is characterized by high production of vegetables including Ethiopian eggplant, preferably grown in lowlands, along the river or streams. This village is one of the large agricultural zone of the country and the user of a large quantity of pesticides [16, 33]. Field observations were set up in 11 plots located in four quarters (Figure 1): Bagachi $\left(5^{\circ} 29^{\prime} 35.41^{\prime \prime} \mathrm{N}, 10^{\circ} 15^{\prime} 51.58^{\prime \prime} \mathrm{E}\right.$; altitude: $1,428 \mathrm{~m}$ a.s.l), Bakeng $\left(5^{\circ} 28^{\prime} 52.87^{\prime \prime} \mathrm{N}, 10^{\circ} 16^{\prime} 28.86^{\prime \prime} \mathrm{E}\right.$; altitude: $1,406 \mathrm{~m}$ a.s.l), Kensap ( $5^{\circ} 29^{\prime} 43.09^{\prime \prime} \mathrm{N}, 10^{\circ} 16^{\prime} 26.94^{\prime \prime} \mathrm{E}$; altitude: 1,398 $\mathrm{m}$ a.s.1), and Medou $\left(5^{\circ} 29^{\prime} 26.81^{\prime \prime} \mathrm{N}, 10^{\circ} 16^{\prime} 16.20^{\prime \prime} \mathrm{E}\right.$; altitude: $1,417 \mathrm{~m}$ a.s.l). In these quarters, monoculture plots of potato plants and those of eggplant plants are present and therefore subjected to the same environmental constraints [34]. These plots are surrounded by food crops and fallows. The prevailing climate is humid tropical subequatorial of high altitude and is classified as "Aw" by Köppen and Geiger [35]. This climate is characterized by the coolness and the humidity due to the high altitude. The raining pattern divides the year into two seasons of unequal duration: a long wet season of 8 months (mid-March to mid-November with the peak of rains in August-September, period during which up to $345 \mathrm{~mm}$ of rainfall can be recorded) and a short dry season 
of 4 months (mid-November to mid-March) [36-38]. As for temperatures, rainfalls are very close to those of the Dschang station. They are relatively low (annual mean value: $20.4^{\circ} \mathrm{C}$ ) and constant due to the high altitude $(1,340 \mathrm{~m}$ a.s.1). The annual average of rainfall is $1,560.3 \mathrm{~mm}$ and the annual thermal amplitude, between the hottest month (March: $21.5^{\circ} \mathrm{C}$ ) and the coolest one (August: $18.9^{\circ} \mathrm{C}$ ) is around $2.6^{\circ} \mathrm{C}$. Over the field investigation period, climatic data from the Dschang station revealed that the mean monthly temperature was $20.2^{\circ} \mathrm{C}$ for cropping season (MarchNovember) and mean monthly rainfall was $208.9 \mathrm{~mm}$ [37, 38]. The soil is hydromorphic type at the level of lowlands used for vegetable crops and it is sandy-clay or ferralitic type in higher areas. Dominant vegetation type is made up of food crops and market gardens. Lands with no human action are rare.

\subsection{Sample Design}

In four quarters of the village, we randomly selected five farmers who granted us access to their eggplant plots. A total of 11 plots were retained, divided into four unmaintained plots (A1, D, F1 and F4) and seven well-maintained plots (A2, A3, B, C, E, F2 and F3). Unlike well-maintained plots, unmaintained plots were weeded. The plot surface varied from 24 to $800 \mathrm{~m}^{2}$ (mean \pm se: $268.5 \pm 65.9 \mathrm{~m}^{2}$ ) and consisted of 60 to 410 plants $\left(225 \pm 35\right.$ plants; one to four plants $/ \mathrm{m}^{2}$; $2 \pm 1$ plants for $n=11$ plots). A distance of three meters spaced plots from each other. A space of three meters wide separates plots from neighbouring fallows and food cops. In each plot, seedlings from the nursery were transplanted in rows. On each row, the gap between two neighbouring seedlings varied from 0.7 to $1.2 \mathrm{~m}(0.97 \pm 0.16 \mathrm{~m} ; 2468$ seedlings $)$. Eggplant plants were categorized into four development stages. Stage 1 plants (St1) were the transplanted seedlings. Stage 2 plants (St2) were plants in the fruits setting phase characterized by the intensive development of leaves, the progressive lengthening of the stems and branches and the appearance of flower buds. Stage 3 plants (St3) or flowering phase plants, were plants with blooming flowers. Stage 4 plants (St4) were plants in the fruiting phase, characterized by the senescence and the fall of leaves and ripe fruits. The controlled plots were divided into one plot of St2 plants (the well-maintained plot A2), two plots of St3 plants (the well-maintained plots F2 and F3) and eight plots of St4 plants (four unmaintained plots A1, D, F1 and F4 and four well-maintained plots A3, B, $\mathrm{C}$ and $\mathrm{E})$. Then the unmaintained plots contained only St4 plants. Given the absence of technical advice, market gardeners do carry out one to two early treatments per week and treatments started at 21 days after seedling transplantation, applied on St2, St 3 and St4 plants. Fourteen days after the transplantation of seedlings, plots were chemically treated once a month between 7 and 9 a.m. or between 12 and 5 p.m. (some treatments being carried out during the hottest hours of the day from 12 to 2 p.m.). Treatments were conducted simultaneously or alternatively with a mixture of four categories of chemicals approved in Cameroon and frequently used by farmers [31, 32, 34, 39]: insecticides, foliar fertilizer, fungicides and herbicide. Insecticides were cigogne 50EC 494/09/IN (cypermethrin 50 $\mathrm{g} / \mathrm{l} ; 750 \mathrm{ml}$ p.c/ha), parastar 40EC 535/10/IN (20 g/l imidacloprid and $20 \mathrm{~g} / 1$ lamda-cyhalothrin; 11 p.c./ha), plantirel 220EC 699/12/IN (20 g/l cypermethrin and $200 \mathrm{~g} / \mathrm{l}$ chlorpyriphos-ethyl; 11 p.c./ha), and diamond fast 751/12/I" (bifenthrin $50 \mathrm{~g} / 1$ and novaluron $50 \mathrm{~g} / \mathrm{l}$; dosage: 11 p.c./ha). Organic foliar fertilizer (2.0-5 1/ha) was a water-soluble mixture sprayed on the foliage during dry weather every 10 to 12 days after transplantation of seedlings. Fungicides were kozeb 80WP 754/12/FO or penncozeb 80WP 472/08/FO which are dispersible concentrate of mancozeb $800 \mathrm{~g} / \mathrm{kg}$ (dithiocarbonate; dosage: 1,7-2,5 kg/ha). Herbicide "Glyso Super Plus" 798/13/HE (glyphosate of ammonium salt 777 $\mathrm{g} / \mathrm{kg}$ : dithiocarbonate; $1,3 \mathrm{~kg} / \mathrm{ha}$ ). Seedlings transplanted in July were monitored every day from 8 a.m. to 2 p.m. until the harvest and the development stage of plants was noted each controlling day. During the week of the last chemical treatment, we cleared the plots of all perforated stems scarified fruits, damaged flowers and leaves. Insects were collected from the $14^{\text {th }}$ day after transplanting and continued until the harvest of fruits. The state of cleanliness of the plots was noted according to their invasion or not by weeds. The plots have been distributed as one well-maintained plot with fruit setting phase plants, two well-maintained plots with flowering phase plants, four well-maintained plots with fruiting phase plants and four unmaintained plots with fruiting phase plants. Fruits were categorized into three development stages. Category 1 fruits (Cat1) were dark green colour immature fruits of small size. Category 2 fruits (Cat2) were light green colour immature fruits of large size. Category 3 fruits (Cat3) were ripe red colour mature fruits. During the capture of insects, in each plot, eggplant plants were inspected twice a week from 7 a.m. to 3 p.m. each day and insects found on the surface of aerial plant organs (stem, branches, leaves, flowers and fruits) were captured using brushes (case of very small insects) or soft forceps (case of large non-flying insects) or using a vacuum cleaner. Flying insects were sampled using a sweep net or a spray insecticide. Captured specimens were kept in labelled vials containing $70^{\circ}$ alcohol. Adults of butterflies were conserved in A4 size paper devices folded to keep the wings intact. Scarified stems and fruits were collected and checked every day in laboratory until the release of adult insects. Caterpillars and other larvae were collected and reared in laboratory.

\subsection{Damage to Aerial Plant Organs}

Insect damages were assessed and described based on visual inspection of aerial vegetal organs. Types of damages caused by insects on leaves and fruits as well as the mode of attack were noted. We noted on each plant and each plot, the number of healthy stems, leaves, flowers and fruits and those attacked by insects. We recorded on the surface of the soil and under each plant, the number of aborted flowers and fruits damaged by insects (presence of black scarring spots). A sample of 10 stems with perforations was taken in each plot and monitored in the laboratory until the emergence of 
adult borers. Lepidoptera phytophagous larvae were collected on leaves and reared in the Laboratory until the emergence of adults. Damaged fruits (recognized by the presence of perforations or black spots) were harvested and opened using a knife in order to certify the presence of insect larvae and therefore to distinguish attacks by insects and attacks by other agents (rots or viruses, bacteria or fungi).

\subsection{Laboratory Rearing}

The rearing materials consisted of plastic containers (diameter: $37 \mathrm{~cm}$; deep: $12 \mathrm{~cm}$ ) covered with a fine-mesh fabric netting for natural ventilation, in which were separately stored the specimens of stems and fruits suspected of attack by insect larvae. Only one type of plant organ was placed in one container. In each container, 20 pieces of scarified plant organ were placed. A total of 1,440 damaged fruits were reared in 72 plastic containers while 200 pieces of scarified stems were reared in 10 plastic containers. We followed the protocol described by Ngamaleu-Siewe [34]. Samples of plant organs were first placed on sterilized sand and two weeks later, the sand was sieved in order to collect pupae. Collected pupae were placed on cotton wool soaked in water until the insect adults emerged. Caterpillars from the field were collected with a sample of leaves of the support plant and placed in the laboratory on a young plant of potato transplanted in pots and watered daily. Rearing containers were checked every day and the emerged adult insects were removed using soft forceps and stored in labelled tubes containing $70^{\circ}$ alcohol. Emerged butterflies were kept in folded A4 paper. We noted the duration of rearing until the day of emergence. For the sampling of stem and fruit borers, 10 attacked stems and fruits were collected in each plot, brought to the laboratory using plastic bags and placed on sterilized and moistened sand. Two weeks later, the sand was sieved, pupae were collected and placed on cotton wool soaked in water until the emergence of insect adults. The butterflies were then kept in carefully folded A4 size paper devices for identification. Collected specimens were placed in the reference collection at the Laboratory of Animal Biology and Physiology, Faculty of Sciences of the University of Douala.

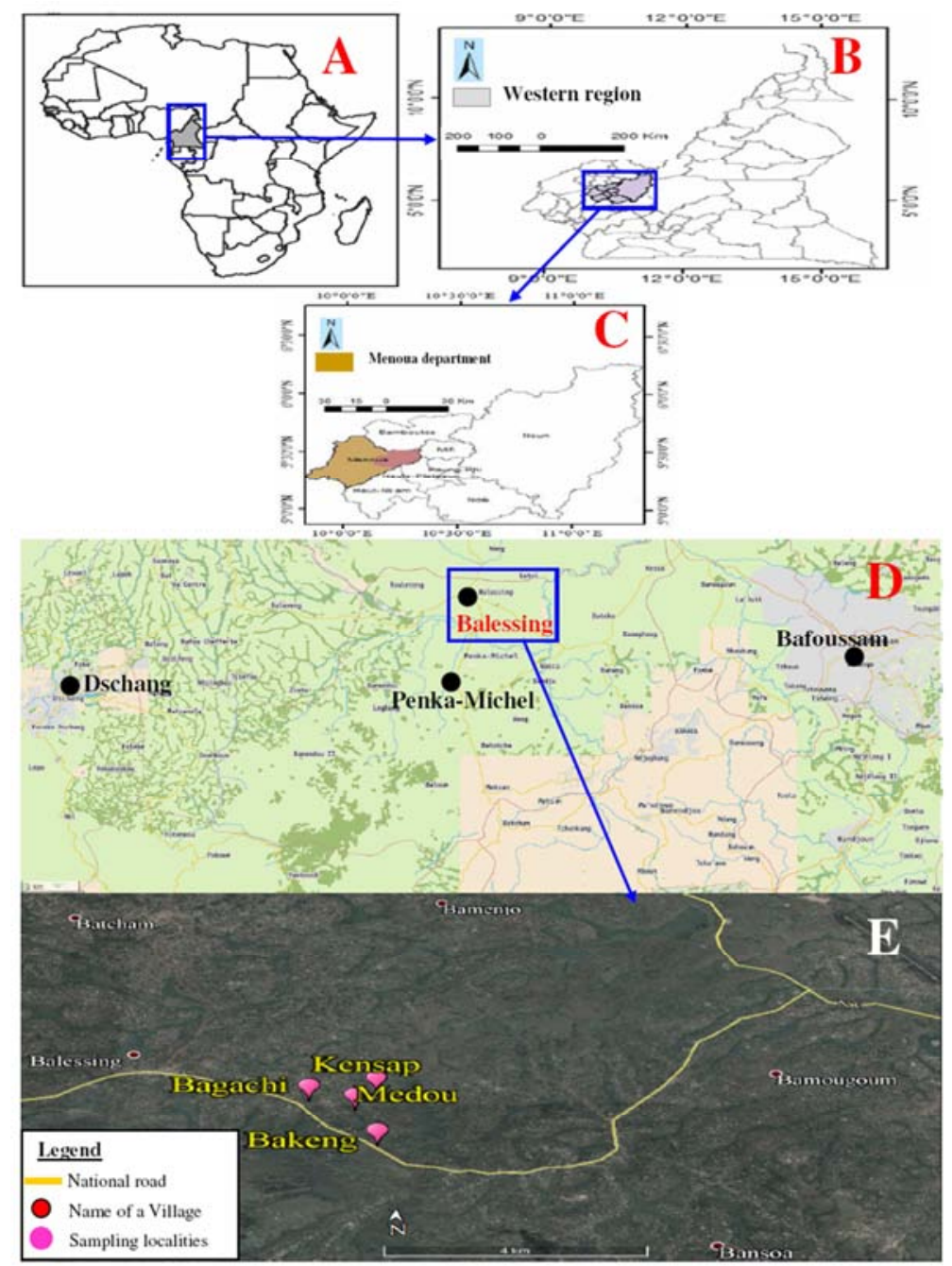

Figure 1. Location of the study locality in Cameroon. A, B and C: Location of Menoua department in the Western region of Cameroon (adapted from Ngamaleu-Siewe et al. [34]), D: Location of Balessing village between Dschang and Bafoussam; E: Location of the sampling sites. 


\subsection{Identification of Insect Specimens}

Collected insects were first identified to the family level using identification keys adapted to insects from tropical zones [12, 40-47]. Specimens were identified to the species level by referring to descriptions and figures available in appropriate keys for Coleoptera [47, 48-55], key for Diptera [56], keys for Hemiptera [43, 57-59], keys for Lepidoptera $[45,46,60,61]$, keys for Coreidae [62] and keys for Orthoptera [63-66]. Identification of species was confirmed by referring to illustrated catalogs and check lists $[44,55]$. In order to consider recent developments in the taxonomy of identified species and their native range, we consulted available reports $[46,53,54,59,60,66-86]$.

\subsection{Statistical Analysis}

Data from the field and the laboratory rearing were stored in a digital format using Excel version 2003 spreadsheet. Simple databases were set up either in the form of species matrix (species abundance, presence/absence of species). Descriptors (species names or variables) were entered in columns and objects (plot code and plant number) were entered in line. Descriptive analysis of qualitative variables is given in terms of relative frequency or percentage of occurrence while discrete quantitative variables (abundance counts) are given in terms of mean \pm standard error (se). Two independents percentages are compared using the Fisher exact test. Two mean values were compared using the Student t-test when the conditions of normality and equality variances passed. Otherwise we used the nonparametric Mann-Whitney rang sum test. Simultaneous comparison of several abundance series was set up using the Kruskal-Wallis test from SigmaStat software 2.0® and pairwise comparisons were set up when relevant using Dunn's procedure because when considering the number of ant species as a metric/response variable, sample units being different, uneven variability could occur between sampling sites. The simultaneous comparison of several percentages was set up using the independent Pearson's chi-square exact test or the Fisher-Freeman-Halton exact-test from StatXact software 3.1, which is one of the best procedure recommended for nonparametric analysis of unordered contingency tables (our situation). When the difference was significant, the pairwise comparison was conducted and the probabilities were adjusted using the sequential Bonferoni procedure summarized by Ngamaleu-Siewe [34]. Regression equation was set up and tested using ANOVA procedure and the coefficient of determination was calculated. Statistical analyses were carried out using StatXact software version 3.1 and SigmaStat for MS Windows version 2.03 (SPSS, Inc., Chicago, IL).

Analysis of the species abundance based matrix allowed the determination of 14 indexes using PAST 3.05 software [87]: the abundance of the $i^{\text {th }}$ species, the sample size, the maximum abundance, the observed species richness, the Margalef index, the richness ratio, the Shannon-Weaver's index, the Simpson index, the Hill's number one index, the Hill's number two index, Hill diversity ratio, the Pielou's index, Hill's evenness index, and Berger-parker index. Comparison of the species richness was performed using the individual rarefaction procedure. The non parametric estimation Chao 1 was used to estimate the theoretical species richness $\mathrm{T}$ and the sampling effort was estimated as $(\mathrm{S} / \mathrm{T}) \times 100$.

The overall species covariance was evaluated using Schluter's procedure summarized by Ngamaleu-Siewe [34]. Between species correlations was evaluated using Kendall's tau coefficient. The dissimilarity between plots and plant stages was evaluated using Bray-Cutis index [88].

The rank abundance plotting was used to illustrate the shape of the species abundance distribution (SAD). The SAD curves were set up using the procedure described by Ngamaleu-Siewe [34]. For the present study, we used five commonly used theoretical SAD models to fit our curves [34, 89, 90]: Broken-stick model (BS), Geometric model (GM), Lognormal model (LM), Zipf model (Z) and ZipfMandelbroot model (ZM). The best fitted model was selected using AIC procedure summarized by Johnson and Omland [91]. The package vegan of R 3.4.1 software [92] helped us to to adjust the SADs of the studied communities. Parameters of the best fitted theoretical model were determined. The mean abundance $\mathrm{x}$ for BS model was determined [93]. We determined the maximum abundance $\mathrm{n}_{1}$ of the first-rang species and the Motomura's environment constant $m$ (decay rate of abundance per rank) for GM model. For $\mathrm{Z}$ models we determined the scaling parameter $\mathrm{Q}$ (normalizing constant) very often taken as equal to the sample size, and $\gamma$ (gamma) parameter representing the decay coefficient or the average probability of the appearance of a species $[94,95]$. Three parameters [Q, $\gamma$ and $\beta$ (beta)] were determined for ZM model where $\beta$ represented the degree of the niche diversification. We calculated $1 / \gamma$ which represented the fractal dimension of the distribution of individuals among species. The nonlinear least squares algorithm of Marquardt [96] summarized by Le et al. [97] and Murthy [98], was used to estimate the maximum values of $\beta$ and $\gamma$ of the best fitted ZM model.

\subsection{Abbreviations}

a.s.l: above sea level, AIC: Akaike Information Criteria, $B$. crepitans: Brachinus crepitans (Linné, 1758), BC: BrayCurtis dissimilarity index, BIC: Bayesian Information Criteria, BS: Broken-stick model, Cat1: Category 1 fruits, Cat2: Category 2 fruits, Cat3: Category 3 fruits, $C h$. sexpunctata: Charidotella sexpunctata (Fabricius, 1781), Chao 1: Chao's Abundance based non-parametric estimators of the species richness, Ci. compta: Chirista compta (Walker, 1870), Co. stenoptera: Coryphosima stenoptera (Schaum, 1853), Cy. aeruginosa: Cyrtacanthacris aeruginosa (Stoll, 1813), d: Richness ratio, D: Simpson index, df: degree of freedom, D. volkeri: Dysdercus volkeri (Schmidt, 1932), E. rufomarginata: Edessa rufomarginata (De Geer, 1773), E( $\left.\mathrm{S}_{\mathrm{n}}\right)$ : 
expected species richness for a theoretical sample of $\mathrm{n}$ individuals, G. acuteangularis: Gonocerus acuteangularis (Goeze, 1778), GM: Geometric series theoretical model, $\mathrm{I}_{\mathrm{BP}}$ : Berger-parker dominance index, J: Pielou evenness index, $\mathrm{H}$ : Kruskal-Wallis test, H': Shannon-Weaver diversity index, $H$. armigera: Helicoverpa armigera (Hubner 1808), La. villosa: Lagria villosa (Fabricius, 1781), Le. orbonalis: Leucinodes orbonalis (Guenee, 1854), LM Lognormal model, Lp. occidentalis: Leptoglossus occidentalis Heidemann, 1910, m: Motomura's environment constant, Ma. sexta: Manduca sexta Linnaeus, 1763, Mg: Margalef richness index, Mo. cubrosa: Mormidea cubrosa (Dallas, 1851), Mo. ypsilon: Mormidea ypsilon (Linnaeus, 1758), $\mathrm{n}_{\mathrm{i}}$ : Absolute abundance of species, $\mathrm{N}_{1}$ : Hill's number one index, $\mathrm{N}_{2}$ : Hill's number two index, $N$. ferruginea: Neocrepidodera ferruginea (Scopoli, 1763), p: statistical probabilities, Pa. notatus: Parapropacris notatus (Karsch, 1891), Ph. grenieri: Phrissotrichum grenieri (Desbrochers, 1875), Pr. cuprea: Protaetia cuprea (Fabricius, 1775), Q: scaling parameter also called the normalizing constant, S: species richness (total number of species), SAD; Species Abundance Distribution, $r$ : Pearson correlation coefficient, $\mathrm{r}^{2}$ : linear regression's coefficient of determination, se: standard error, Se. halensis: Sermylassa halensis (Linnaeus, 1767), So. aethiopicum: Solanum aethiopicum Linnaeus, 1756, So. macrocarpon: Solanum macrocarpon Linnaeus. 1771, So. melongena: Solanum melongena Linnaeus, 1753, Sp. annulus: Sphaerocoris annulus (Fabricius, 1775), St. sardoa: Stenosis sardoa (Küster, 1848), St1: development stage 1 plants, St2: development stage 2 plants, St3: development stage 3 plants, St4: development stage 4 plants, $\tau$ : Kendall's tau correlation, T: Theoretical species richness, T. ferruginea: Taphronota ferruginea (Fabricius, 1781), VR: Schluter's Variance ratio, Z: Zipf model, ZM: Zipf-Mandelbroot model, $\alpha$ ': Bonferoni adjusted significance level, $\beta$ (beta): the degree of the niche diversification, $\gamma$ (gamma): decay coefficient or the average probability of the appearance of a species, $\chi^{2}$ : chi-square statistic.

\section{Results}

\subsection{Insects Associated with Eggplant Plants}

Insects from the field collection belonged to four orders (Coleoptera Linnaeus, 1758, Hemiptera Linnaeus, 1758, Lepidoptea Linnaeus, 1758 and Orthoptera Latreille, 1793) and 13 families [Acrididae Macleay, 1821, Brentidae Billberg, 1820, Carabidae Latreille, 1802, Chrysomelidae Latreille, 1802, Coreidae Leach, 1815, Crambidae Latreille, 1810, Pentatomidae Leach, 1815, Pyrgomorphidae Brunner von Wattenwyl, 1874, Pyrrhocoridae Fieber, 1860, Scarabaeidae Latreille, 1802, Scutelleridae Leach, 1815, Sphingidae Latreille, 1802 and Tenebrionidae Latreille, 1802] (Table 1). Insects from the laboratory rearing belonged to one order (Lepidoptera Linnaeus, 1758), and two families (Crambidae Latreille, 1810 and Noctuidae Latreille, 1809). We therefore recorded a total of four orders and 14 families of insects associated with eggplant plants.

A total of 1,440 fruits placed in 72 containers allowed the rearing of 1,928 caterpillars (20 to 50 caterpillars per container, mean \pm se; $27 \pm 1$ caterpillars per container). Pupae were obtained after three to 16 days ( $9 \pm 0$ days) and from the pupa appearance day, 1,246 adult insects emerged eight to 20 days later ( $12 \pm 0$ days). The percentage of emergence was $64.6 \%$. The insects that emerged were two Lepidoptera species. From 198 caterpillars reared using 160 fruits in eight containers, 123 adults of the Noctuidae Helicoverpa armigera (Hubner 1808) emerged after eight to 20 days ( $15 \pm 1$ days) from the appearance date of the pupa, pupae being obtained after eight to 16 rearing days ( $13 \pm 1$ days). Eight to 25 adults emerged (15 \pm 2 adults) per container giving an emergence rate of $6.4 \%$. From 1,730 caterpillars reared using 1,280 fruits in 64 containers, 1,123 adults of the Crambidae Leucinodes orbonalis Guenee, 1854 emerged (six to 36 adults per container, $18 \pm 1$ adults per container). Pupae were recorded after three to 12 days, i.e. $9 \pm 0$ days and adults emerged after eight to 15 days, i.e. $12 \pm 0$ days from the appearance date of the pupa. and the emergence percentage was $58.2 \%$.

A total of 241 caterpillars installed inside the tissues of 200 scarified stems were placed in 10 containers (20 to 30 caterpillars per container and $24 \pm 1$ caterpillar per container). The pupae were formed after six to 10 days ( $8 \pm 0$ days). Adult insects (84 individuals, three to 30 individuals per container, $8 \pm 3$ individuals per container) emerged after nine to 14 days ( $11 \pm 0$ days). The percentage of emergence was $34.9 \%$ and in all cases the Lepidoptera Crambidae Le. orbonalis was recorded. The percentage of adults' emergence was higher from fruits than stems (Fisher exact test: $\chi^{2}=77.69, \mathrm{df}=1$, $\left.\mathrm{p}=1.94 \times 10^{-19}\right)$.

Based on the field collection, Coleoptera was highly represented $(46.2 \%)$, followed by Hemiptera (30.8\%), Lepidoptera (15.4\%) and Orthoptera (7.7\%). The variation in percentages was globally not significant (Fisher-FreemanHalton exact test: $\chi^{2}=5.67, \mathrm{df}=3, \mathrm{p}=0.136$ ). This was also the situation in well-maintained plots ( 7 families, $28.6 \%$ of Coleoptera, $42.9 \%$ ot Hemiptera, $14.3 \%$ of Lepidoptera and Orthoptera respectively, Fisher-Freeman-Halton test: $\chi^{2}=2.04$, $\mathrm{df}=3, \mathrm{p}=0.781$ ). It was also the case in unmaintained plots ( 13 families, $\chi^{2}=5.67, \mathrm{df}=3, \mathrm{p}=0.136$ ). No order was recorded exclusively in well-maintained plots. The variation in percentage was not significant between orders recorded exclusively in unmaintained plots (six families, 66.7\% of Coleoptera and $16.7 \%$ of Hemiptera and Lepidoptera respectively, $\chi^{2}=6.56, \mathrm{df}=3, \mathrm{p}=0.089$ ). It was also the case between orders recorded simultaneously in well-maintained and unmaintained plots (seven families, $28.5 \%$ for Coleoptera, $42.9 \%$ for Hemiptera and $14.3 \%$ for Lepidoptera and Orthoptera respectively, $\chi^{2}=2.04, \mathrm{df}=3, \mathrm{p}=0.781$ ).

A total of 155 specimens collected in the field corresponded to 21 genera and 22 species (Table 1). Overall the variation in percentages was significant (Pearson's chi-square: $\chi^{2}=70.44$, $\mathrm{df}=42, \mathrm{p}=0.004)$ and the same was true for well maintained plots (42 specimens, 9 species, $\chi^{2}=51.62, \mathrm{df}=16, \mathrm{p}=1.3 \times 10^{-5}$ ) and 
unmaintained plots (113 specimens, 22 species, $\chi^{2}=237.32$, $\mathrm{df}=21, \mathrm{p}<0.001)$. We identified four species of Acrididae (18.2\%) [3.2\% for Chirista compta (Walker, 1870), 1.9\% for Coryphosima stenoptera (Schaum, 1853), 3.2\% for Cyrtacanthacris aeruginosa (Stoll, 1813) and $1.9 \%$ for Parapropacris notatus (Karsch, 1891), i.e. $10.3 \%$ of the total collection]. One species of Brentidae (4.5\%) was recorded [Phrissotrichum grenieri (Desbrochers, 1875), 1.3\% of the total collection]. From the same collection we identified one species of Carabidae (4.5\%) [Brachinus crepitans (Linné, 1758), 0.6\% of the total collection], one species of Cetonidae (4.5\%) [Protaetia cuprea (Fabricius, 1775), $0.6 \%$ of the total collection] Three species of Chrysomelidae (13.6\%) were recorded [1.9\% for Charidotella sexpunctata (Fabricius, 1781), 1.3\% for Neocrepidodera ferruginea (Scopoli, 1763) and 1.3\% for Sermylassa halensis (Linnaeus, 1767), i.e. $4.5 \%$ of the total collection]. We also identified two species of Coreidae (9.1\%) [5.8\% for Gonocerus acuteangularis (Goeze, 1778) and 1.9\% for Leptoglossus occidentalis Heidemann, 1910, i.e. 7.7\% of the total collection], one species of Crambidae (4.5\%) [Le. orbonalis, $38.1 \%$ of the total collection], three species of Pentatomidae (3.6\%) [3.2\% for Edessa rufomarginata (De Geer, 1773), 7.7\% for Mormidea cubrosa (Dallas, 1851) and 3.2\% for Mo. ypsilon (Linnaeus, 1758), i.e. $14.1 \%$ of the total collection]. More over, we identified one species of Pyrrhocoridae (4.5\%) [Dysdercus volkeri (Schmidt, 1932), 7.7\% of the total collection]. We also recorded one species of Pyrgomorphidae (4.5\%) [Taphronota ferruginea (Fabricius, 1781), 3.9\% of the total collection], one species of Scutelleridae (4.5\%) [Sphaerocoris annulus (Fabricius, 1775), 5.2\% of the total collection], one species of Sphingidae (4.5\%) [Manduca sexta Linnaeus, 1763, $0.6 \%$ of the total collection]. From the same collection we identified two species of Tenebrionidae (9.1\%) [0.6\% for Lagria villosa (Fabricius, 1781) and 4.5\% for Stenosis sardoa (Küster, 1848), i.e. $5.1 \%$ of the total collection]. By combining the data from laboratory rearings and those from field collections, a total of 23 species were recorded. Based on the species composition, Acrididae was the most represented $(18.2 \%)$, followed by Chrysomelidae and Pentatomidae (13.6\% respectively), by Coreidae and Tenebrionidae (9.1\% respectively). The remaining eight families (Brentidae, Carabidae, Cetonidae, Crambidae, Pyrgomorphidae, Pyrrhocoridae, Scutelleridae and Sphingidae) were rare $(4.5 \%$ respectively) (Table 1$)$. No species was recorded exclusively on $\mathrm{St} 2$ and $\mathrm{St} 3$ plants. A total of 18 species (81.8\%) (B. crepitans, Ch. sexpunctata, Ci. compta, Co. stenoptera, D. volkeri, G. acuteangularis, La. villosa, Lp. occidentalis, Ma. sexta, Mo. cubrosa, Mo. ypsilon, N. ferruginea, Pa. notatus, Ph. grenieri, Pr. cuprea, Se. halensis, Sp. annulus, T. ferruginea) were recorded exclusively on St 4 plants. Two species (9.1\%) (Cy. aeruginosa and E. rufomarginata) were recorded simultaneously on St 2 and St 4 plants. Two other species $(9.1 \%)$ (Le. orbonalis and St. sardoa) were recorded simultaneously on St 3 and St 4 plants. The percentage of species found exclusively on St4 plants (49.7\%) was not significantly different from that of species found on several plant development stages (49.0\%) (Fisher exact test: $\chi^{2}=0.018, \mathrm{df}=1$, $\mathrm{p}=1.00$ ) (Table 1). Between the three plant development stages, the variation in species richness was significant (FisherFreeman-Halton test: $\chi^{2}=56.24 ; \mathrm{df}=2 ; \mathrm{p}=2.46 \times 10^{-13}$ ). Pairwise comparison showed significant difference between St2 (2 species) and St4 (22 species) plants (Bonferoni corrected significance level $\left.\alpha^{\prime}=0.017, \mathrm{p}=2.62 \times 10^{-10}\right)$, and between St3 (2 species) and St 4 plants $\left(\alpha^{\prime}=0.025, \mathrm{p}=2.62 \times 10^{-10}\right)$ while the difference was not significant between St2 ant St3 plants $(\alpha=0.05, p=1.00)$. The differences in the median values of the species abundance among the three development stages was not significant difference (Kruskall-Wallis test: $\mathrm{H}=1.298$, $\mathrm{df}=2$, $\mathrm{p}=0,523)$.

According to the cleanliness of the plots, no species was recorded exclusively in the well-maintained plots while 13 species $(59.1 \%)$ were recorded exclusively in the unmaintained plots (B. crepitans, Ch. sexpunctata, Ci. compta, Co. stenoptera, D. volkeri, La. villosa, Lp. occidentalis, Ma. sexta, N. ferruginea, Pa. notatus, Ph. grenieri, Pr. cuprea, T. ferruginea). Nine species (40.9\%) were recorded simultaneously in the well-maintained and unmaintained plots (Cy. aeruginosa, E. rufomarginata, $G$. acuteangularis, Le. orbonalis, Mo. cubrosa, Mo. ypsilon, Se. halensis, Sp. annulus, St. sardoa). The percentage of species found exclusively in unmaintained plots did not differ from that recorded simultaneously in well-maintained and unmaintained plots (Fisher exact test: $\chi^{2}=1.43, \mathrm{df}=1, \mathrm{p}=0.366$ ) (Table 1). The difference in the median values between the two groups is not significant (Mann-Whitney test: $\mathrm{T}=121.0$, $\mathrm{P}=0,242$ ).

Based on the trophic behaviour of the collected insects, we recorded 15 phytophagous species $(68.2 \%$ of the total richness, $32.9 \%$ of the total collection). Among these phytophagous insects five species $(22.7 \%$ of the total richness, $12.3 \%$ of the total collection) (La. villosa, Lp. occidentalis, Ma. sexta, Sp. Annulus and T. ferruginea) were known as pest, the first two species being invasive. Ten species $(45.5 \%$ of the total richness, $20.6 \%$ of the total collection) (B. crepitans, Ch. sexpunctata, Ci. compta, Co. stenoptera, Cy. aeruginosa, N. ferruginea, Se. halensis, Pa. notatus, Pr. cuprea and St. sardoa) were of unknown pest status (Table 1). We recorded in the field, two borer species (9.1\% of the total richness, $39.4 \%$ of the total collection), including the invasive species Le. orbonalis and the species of unknown pest status $P h$. grenieri $(4.5 \%$ of the total collection respectively). Finally we identified five sapfeeders $(22.7 \%$ of the total richness, $27.7 \%$ of the total collection). Among these sap-sucking species, there are three pest species (D. volkeri, E. rufomarginata and $G$. acuteangularis) $(13.6 \%$ of the total richness, $16.8 \%$ of the total collection) and two species (Mo. cubrosa and Mo. ypsilon) of unknown harmful status $(9.1 \%$ of the total richness, $11.0 \%$ of the total collection). Overall the differences in the median values of abundances among phytophagous species, borer species and sap-feeders were statistically significant (Kruskall-Wallis test: $\mathrm{H}=6.433, \mathrm{df}=2$, $\mathrm{p}=0,040$ ). Pairwise comparisons using Dunn's procedure between sap-feeders and phytophagous species (Dunn's test: $\mathrm{q}=2.445, \mathrm{p}<0.05$ ) while it was the contrary when comparing 
borer species to sap-feeders and phytophagous species.

According to the native range, two alien species emerged from the laboratory rearing: $H$. armigera is native to central and southern Europe and Le. orbonalis is native to tropical and subtropical parts of Australia and Asia. Amongst the species collected in the field, nine species were native to Afrotropical region: Ch. sexpunctata, Ci. compta, Co. stenoptera, Cy. aeruginosa, D. volkeri, La. villosa, Pa. notatus, Sp. annulus and T. ferruginea. D. voelkeri a pan tropical distributed species. Thirteen species were alien species. Seven species are native to the Palaearctic region: $B$. crepitans (Western Palaearctic and Saharo-Arabian distribution), G. acuteangularis (Holomediteranean to Central American distribution), N. ferruginea (Western Palaearctic distribution), Ph. grenieri (European distribution), Pr. cuprea (Central European distribution), Se. halensis (European to Central American distribution) and St. sardoa (European distribution). Amongst the non-native species five species are frequently reported in the Neartic region: $E$. rufomarginata (American distribution), Lp. occidentalis (Western North American distribution), Ma. sexta, Mo. cubrosa and Mo. ypsilon (American distribution respectively) We recorded one species (Le. orbonalis) widely distributed in the Indomalasian region especially in the tropical and subtropical Australia and Asia. The difference between the species percentage of alien species $(59.1 \%$ of the total richness) and that of native species $(40.9 \%)$ was not significant (Fisher's exact test: $\chi^{2}=1.432, \mathrm{df}=1, \mathrm{p}=0.366$ ) while alien species were highly recorded $(70.3 \%$ of the total collection) than native species (29.7\%) (Fisher exact test: $\left.\chi^{2}=52.371, \mathrm{df}=1, \mathrm{p}=9.3 \times 10^{-13}\right)$ (Table 1).

\subsection{Species Abundance}

A total of 155 specimens (mean \pm se: $7 \pm 3$ specimens, 22 species) were collected in the field. These specimens were divided into four specimens $(2.6 \%$ of the total collection) of two species (9.1\% of the total richness) from St2 plants, eight specimens $(5.2 \%$ of the total collection, two species, $9.1 \%$ of the total richness, $4 \pm 3$ specimens) from St3 plants, and 143 specimens $(92.3 \%$ of the total collection, 22 species, $100.0 \%$ of the total richness, $7 \pm 2$ specimens) from St 4 plants. No specimen was recorded exclusively in plots of St2 and St3 plants. Seventy nine specimens $(51.0 \%$ of the total collection, 18 species, $81.8 \%$ of the total richness) were collected exclusively in plots of St 4 plants. Ten specimens $(6.5 \%$ of the total collection, 2 species, $9.1 \%$ of the total richness) were collected simultaneously in St 2 and St 4 plants. Sixty six specimens $(42.6 \%$ of the total collection, 2 species, $9.1 \%$ of the total richness) were collected simultaneously in plots of St 3 and St4 plants. This makes for cosmopolitan species, 76 specimens (49.0\% of the total collection, four species, $18.2 \%$ of the total richness) recorded simultaneously on two plant development stages. The difference between the species percentage recorded exclusively on a single plant development stage and that of cosmopolitan species was not significant (Fsher exact test: $\chi^{2}=0.180, \mathrm{df}=1, \mathrm{p}=0.820$ ).

Based on the cleanliness of plots, no specimen was recorded exclusively in well-maintained plots while 43 specimens $(27.7 \%$ of the total collection, 13 species i.e. $59.1 \%$ of the total richness) were recorded exclusively in unmaintained plots. A total of 112 specimens $(72.3 \%$ and nine species i.e. $40.9 \%)$ were collected simultaneously in well-maintained and unmaintained plots. The difference between the species percentage recorded exclusively on a single type of plots and that of cosmopolitan species was not significant (Fisher's exact test: $\chi^{2}=1.432, \mathrm{df}=1, \mathrm{p}=0.366$ ) but cosmopolitan species were highly represented than species recorded exclusively on a single type of plots (Fisher's exact test: $\left.\chi^{2}=43.207, \mathrm{df}=1, \mathrm{p}=3.98 \times 10^{-15}\right)$. Species abundances did not vary significantly between the sample medians of the three development stages (Kruskall-Wallis multiple test: $\mathrm{H}=1.298$, $\mathrm{df}=2, \mathrm{p}=0.523$ ). Percentages did not vary significantly between the three development stages (Fisher-Freeman-Halton test: $\left.\chi^{2}=53.891 ; \mathrm{df}=42 ; \mathrm{p}=0.233\right)$. According to the cleanliness of plots, no significant difference was noted between sample medians of the distribution in the well-maintained plots (42 specimens, median value: 2 , mean \pm se: $5 \pm 2$ specimens; 9 species) and that noted in the unmaintained plots (113 specimens, median value: $3,5 \pm 2$ specimens; 22 species) (Mann-Whitney Rank Sum test: $\mathrm{T}=125.5 ; \mathrm{p}=0.433$ ) (Tables 1 and 2). Alien species (109 specimens; $8 \pm 4$ specimens, 13 species, $59.1 \%$ of the total richness) were highly represented than Afrotropical native species (46 specimens, $5 \pm 1$ specimens, 9 species, $40.9 \%$ of the total richness). There was no significant difference between sample medians of native and alien species abundances (Mann-Whitney Rank Sum test: $\mathrm{T}=112.5 ; \mathrm{p}=0.570$ ).

\subsection{Community Structure}

Among the plant development stages, species richness was very high in St 4 plants (22 species, $100.0 \%$ of the overall species richness, Margalef index: $\mathrm{Mg}=0.231$, ShannonWeaver index: $H^{\prime}=2.424$ ) while $\mathrm{St} 2$ plants (two species, 9.1\%, $\mathrm{Mg}=0.721, \mathrm{H}^{\prime}=0.693$ ) and $\mathrm{St} 3$ plants (two species, $\left.9.1 \%, \mathrm{Mg}=0.481, \mathrm{H}^{\prime}=0.377\right)$ presented low species richness (Table 2). The species richness was high in unmaintained plots (22 species, $\left.100.0 \%, \mathrm{Mg}=4.442, \mathrm{H}^{\prime}=2.509\right)$ and nonnative species (13 species, $\left.59.1 \%, \mathrm{Mg}=2.558, \mathrm{H}^{\prime}=1.688\right)$. It was low in well-maintained plots ( 9 species, $40.9 \%$, $\mathrm{Mg}=2.140, \mathrm{H}^{\prime}=1.519$ ) and in native species (nine species, $40.9 \%, \quad \mathrm{Mg}=2.090, \mathrm{H}^{\prime}=2.020$ ) (Table 2). Low species richness was noted. Values of the richness ratio were close to zero. Based on the Chao 1 estimator, the sampling success was very high (100.0\%) respectively in plots of St2 and St4 plants and in native species. A low score (81.5\%) was recorded in unmaintained plots (Table 2). Difference in diversity indexes was significant between well-maintained and unmaintained plots and between native and non-native species categories. A low species diversity was recorded (Shannon-Weaver index were close to the median value while values of the Simpson's index were closed to zero except in plots of St2 and St3 plants). We noted a high even community except St3 plants and a low dominance by a few species except St2 and St3 plants, well-maintained plots and the alien species (Table 2). The rank-abundance plotting of the pooled data presented a concave appearance suggesting 
the presence of co-dominant species (Figure 2). The same shape of the graph was observed in well-maintained plots (Figure 3A), unmaintained plots (Figure 3B), native species (Figure $3 \mathrm{C}$ ) and the non-native species community (Figure 3D). Based on the Hill's $\mathrm{N}_{2}$ index (Table 2), E. rufomarginata and Cy. aeruginosa co-dominated the community in St2 plants. Le. orbonalis dominated the St3 plants. Six species co-dominated the St4 plants: D. volkeri, G. acuteangularis, Le. orbonalis, Mo. cubrosa, Sp. annulus and
St. sardoa. According to the cleanliness of plots three species co-dominated the well-maintained plots: Le. orbonalis, Mo. cubrosa and Sp. annulus. Seven species co-dominated the community of unmaintained plots: $D$. volkeri, $G$. acuteangularis, Le. orbonalis, Mo. cubrosa, St. sardoa and T. ferruginea.

According to the native range, seven species co-dominated Afrotropical native species: $C h$. sexpunctata, $C i$. compta, $C y$. aeruginosa, D. volkeri, Sp. annulus and T. ferruginea.

Table 1. Absolute and relative abundance of Insect species in unmaintained and well-maintained plots of Ethiopian eggplant plants and the damaged plant ogans.

\begin{tabular}{|c|c|c|c|c|c|}
\hline ORDER / Familly & Species's name & Status & Native range & Reference & Damaged plant organs \\
\hline \multicolumn{6}{|l|}{ COLEOPTERA } \\
\hline Brentidae & Phrissotrichum grenieri (Desbrochers, 1875) & $\#, ?$ & $\mathrm{PA}(\mathrm{EU})$ & {$[54,66-68]$} & Stems \\
\hline Carabidae & Brachinus crepitans (Linné, 1758) & $*, ?$ & PA (WPA-SAR) & {$[47-49,66,68]$} & Leaves \\
\hline \multirow[t]{3}{*}{ Chrysomelidae } & Charidotella sexpunctata (Fabricius, 1781) & $*, ?$ & TAF & {$[47-49,66,68,70]$} & Leaves \\
\hline & Neocrepidodera ferruginea (Scopoli, 1763) & $*, ?$ & PA (WPA) & {$[52,48,49,66,68,70]$} & Leaves \\
\hline & Sermylassa halensis (Linnaeus, 1767) & $*, ?$ & PA (EU), NT (CA) & {$[48,49,66,68-70]$} & Leaves \\
\hline Scarabaeidae & Protaetia cuprea (Fabricius, 1775) & $*, ?$ & $\mathrm{PA}(\mathrm{CEU})$ & {$[48,49,66,68,71]$} & Leaves \\
\hline \multirow[t]{2}{*}{ Tenebrionidae } & Lagria villosa (Fabricius, 1781) & *,in,pest & TAF & {$[48,49,66,68,72,82]$,} & Leaves \\
\hline & Stenosis sardoa (Küster, 1848) & *,? & $\mathrm{PA}(\mathrm{EU})$ & {$[48,49,55,73,66,68]$} & Leaves, Fruits \\
\hline \multicolumn{6}{|l|}{ HEMIPTERA } \\
\hline \multirow[t]{2}{*}{ Coreidae } & Gonocerus acuteangularis (Goeze, 1778) & $\S$, pest & PA (HM), NE (CA) & {$[62,74]$} & Stems \\
\hline & Leptoglossus occidentalis Heidemann, 1910 & *,in,pest & NE (WNA) & {$[83,84,60-62,76]$} & Leaves \\
\hline \multirow[t]{3}{*}{ Pentatomidae } & Edessa rufomarginata (De Geer, 1773) & $\S$, pest & NE (AM) & {$[59,108]$} & Leaves \\
\hline & Mormidea cubrosa (Dallas, 1851) & $\S, ?$ & NE (AM) & [59] & Leaves \\
\hline & Mo. ypsilon (Linnaeus, 1758) & $\S, ?$ & $\mathrm{NE}(\mathrm{AM})$ & [59] & Leaves \\
\hline Pyrrhocoridae & Dysdercus volkeri (Schmidt, 1932) & $\S$, pest & TAF & {$[58]$} & Leaves \\
\hline Scutelleridae & Sphaerocoris annulus (Fabricius, 1775) & *, pest & TAF & [107] & Leaves \\
\hline \multicolumn{6}{|l|}{ LEPIDOPTERA } \\
\hline Crambidae & Leucinodes orbonalis (Guenee, 1854) & $\#$,in,pest & IM (TAA), AU (STAA) & {$[45,102,110$} & Fruits \\
\hline $\begin{array}{l}\text { Sphingidae } \\
\text { ORTHOPTERA }\end{array}$ & Manduca sexta Linnaeus, 1763 & $*$, pest & $\mathrm{NE}(\mathrm{AM})$ & {$[46,78,79]$} & Leaves \\
\hline \multirow[t]{4}{*}{ Acrididae } & Chirista compta (Walker, 1870) & $*, ?$ & TAF & {$[81,86,64,65]$} & Leaves \\
\hline & Coryphosima stenoptera (Schaum, 1853) & *, ? & TAF & {$[81,86,64,65]$} & Leaves \\
\hline & Cyrtacanthacris aeruginosa (Stoll, 1813) & $* ?$ & TAF & {$[81,86,64,65]$} & Leaves \\
\hline & Parapropacris notatus (Karsch, 1891) & $*, ?$ & TAF & {$[80,81,64,65,86]$} & Leaves \\
\hline Pyrgomorphidae & Taphronota ferruginea (Fabricius, 1781) & *, pest & TAF & {$[80,81,64,65,86]$} & Leaves \\
\hline Sample size & & & & & \\
\hline
\end{tabular}

Table 1. Continued.

\begin{tabular}{|c|c|c|c|c|c|c|}
\hline \multirow{2}{*}{ ORDER / Familly } & \multicolumn{4}{|l|}{ I } & \multirow{2}{*}{ II: St4 (\%) } & \multirow{2}{*}{ Global (\%) } \\
\hline & St2 (\%) & St3 (\%) & St4 (\%) & Total (\%) & & \\
\hline \multicolumn{7}{|l|}{ COLEOPTERA } \\
\hline Brentidae & - & - & - & - & $2(1.3)$ & $2(1.3)$ \\
\hline Carabidae & - & - & - & - & $1(0.6)$ & $1(0.6)$ \\
\hline \multirow[t]{3}{*}{ Chrysomelidae } & - & - & - & - & $3(1.9)$ & $3(1.9)$ \\
\hline & - & - & - & - & $2(1.3)$ & $2(1.3)$ \\
\hline & - & - & $1(0.6)$ & $1(0.6)$ & $1(0.6)$ & $2(1.3)$ \\
\hline Scarabaeidae & - & - & - & - & $1(0.6)$ & $1(0.6)$ \\
\hline \multirow[t]{2}{*}{ Tenebrionidae } & - & - & - & - & $1(0.6)$ & $1(0.6)$ \\
\hline & - & $1(0.6)$ & - & $1(0.6)$ & $6(3.9)$ & $7(4.5)$ \\
\hline \multicolumn{7}{|l|}{ HEMIPTERA } \\
\hline \multirow[t]{2}{*}{ Coreidae } & - & - & $1(0.6)$ & $1(0.6)$ & $8(5.2)$ & $9(5.8)$ \\
\hline & - & - & - & - & $3(1.9)$ & $3(1.9)$ \\
\hline \multirow[t]{3}{*}{ Pentatomidae } & $2(1.3)$ & - & - & $2(1.3)$ & $3(1.9)$ & $5(3.2)$ \\
\hline & - & - & $3(1.9)$ & $3(1.9)$ & $9(5.8)$ & $12(7.7)$ \\
\hline & - & - & $2(1.3)$ & $2(1.3)$ & $3(1.9)$ & $5(3.2)$ \\
\hline Pyrrhocoridae & - & - & - & - & $12(7.7)$ & $12(7.7)$ \\
\hline
\end{tabular}




\begin{tabular}{|c|c|c|c|c|c|c|}
\hline \multirow{2}{*}{ ORDER / Familly } & \multicolumn{4}{|l|}{ I } & \multirow{2}{*}{ II: St4 (\%) } & \multirow{2}{*}{ Global (\%) } \\
\hline & St2 (\%) & St3 (\%) & St4 (\%) & Total (\%) & & \\
\hline Scutelleridae & - & - & $7(4.5)$ & $7(4.5)$ & $1(0.6)$ & $8(5.2)$ \\
\hline \multicolumn{7}{|l|}{ LEPIDOPTERA } \\
\hline Crambidae & - & $7(4.5)$ & $16(10.3)$ & $23(14.8)$ & $36(23.2)$ & $59(38.1)$ \\
\hline Sphingidae & - & - & - & - & $1(0.6)$ & $1(0.6)$ \\
\hline \multicolumn{7}{|l|}{ ORTHOPTERA } \\
\hline \multirow[t]{4}{*}{ Acrididae } & - & - & - & - & $5(3.2)$ & $5(3.2)$ \\
\hline & - & - & - & - & $3(1.9)$ & $3(1.9)$ \\
\hline & $2(1.3)$ & - & - & $2(1.3)$ & $3(1.9)$ & $5(3.2)$ \\
\hline & - & - & - & - & $3(1.9)$ & $3(1.9)$ \\
\hline Pyrgomorphidae & - & - & - & - & $6(3.9)$ & $6(3.9)$ \\
\hline Sample size & $4(2.6)$ & $8(5.2)$ & $30(19.4)$ & $42(27.1)$ & $113(72.9)$ & $155(100.0)$ \\
\hline Species richness & $2(9.1)$ & $2(9.1)$ & $6(27.3)$ & $9(40.9)$ & $22(100.0)$ & $22(100.0)$ \\
\hline
\end{tabular}

St2=development stage 2 plants; St3=development stage 3 plants; St $4=$ development stage 4 plants; I=Well-maintained plots, II=Unmaintained plots, *=phytophagous insect; \#=borer insect; $\S=$ sap feeding insect; ?=unknown pest status; -=not registered; in=invasive species; pest=pest species; -=not recorded; $\mathrm{AM}=\mathrm{American}$ region, $\mathrm{AU}=\mathrm{Australasian}$ region, $\mathrm{CA}=\mathrm{Central}$ America; $\mathrm{TA}=$ Tropical Africa; $\mathrm{CEU}=\mathrm{Central}$ European region, EU=European region; $\mathrm{HO}=$ Holarctic region; $\mathrm{HM}=$ Holomediterranean, $\mathrm{IM}=$ Indomalasian region, $\mathrm{NE}=$ Neartic region; $\mathrm{PA}=$ Palaearctic region; $\mathrm{SAR}=\mathrm{Saharo}-\mathrm{Arabian}$, TAA=Tropical Australia and Asia; $\mathrm{STAA}=$ Subtropical Australia and Asia; TAF=Tropical Africa region, WNA=Western North America, WPA=Western Palaearctic region.

Table 2. Matrix of the species richness, diversity, evenness and dominance indices.

\begin{tabular}{|c|c|c|c|c|c|c|c|c|}
\hline & & & & Cleanliness & & Distribution & & \\
\hline Indices & St2 & St3 & St4 & Well-maintained plots & Unmaintained plots & Native species & Alien species & Global \\
\hline $\mathrm{n}(\%)$ & $4(2.6)$ & $8(5.2)$ & $143(92.3)$ & $42(27,1)$ & $113(72,9)$ & $46(29.7)$ & $109(70.3)$ & $155(100,0)$ \\
\hline $\mathrm{S}(\%)$ & $2(9.1)$ & $2(9.1)$ & $22(100.0)$ & $9(40.9)$ & $22(100.0)$ & $9(40.9)$ & $13(59.1)$ & $22(100.0)$ \\
\hline $\mathrm{n}_{\max }$ & 2 & 7 & 52 & 23 & 36 & 12 & 59 & 59 \\
\hline $\mathrm{Mg}$ & 0.721 & 0.481 & 0.231 & 2.140 & 4.442 & 2.090 & 2.558 & 4.164 \\
\hline $\mathrm{d}$ & 0.500 & 0.250 & 0.154 & 0.214 & 0.195 & 0.196 & 0.119 & 0.142 \\
\hline Chao 1 & 2 & 2 & 24 & 10 & 27 & 9 & 14 & 24 \\
\hline SE $(\%)$ & 100.0 & 100.0 & 93.6 & 92.3 & 81.5 & 100.0 & 94.5 & 93.6 \\
\hline $\mathrm{H}^{\prime}$ & 0.693 & 0.377 & 2.424 & 1.519 & 2.509 & 2.020 & 1.688 & 2.395 \\
\hline $\mathrm{H}_{\text {max }}^{\prime}$ & 0.693 & 0.693 & 3.091 & 2.198 & 3.091 & 2.197 & 2.565 & 3.091 \\
\hline $\mathrm{D}$ & 0.500 & 0.781 & 0.163 & 0.341 & 0.138 & 0.152 & 0.322 & 0.173 \\
\hline $\mathrm{N}_{1}$ & 2 & 1 & 11 & 5 & 12 & 8 & 5 & 11 \\
\hline $\mathrm{N}_{2}$ & 2 & 1 & 6 & 3 & 7 & 7 & 3 & 6 \\
\hline Hill & 1.000 & 0.878 & 0.544 & 0.642 & 0.590 & 0.871 & 0.574 & 0.528 \\
\hline $\mathrm{J}$ & 1.000 & 0.544 & 0.784 & 0.691 & 0.812 & 0.919 & 0.658 & 0.775 \\
\hline $\mathrm{I}_{\mathrm{BP}}$ & 0.500 & 0.875 & 0.364 & 0.548 & 0.319 & 0.261 & 0.541 & 0.381 \\
\hline \multicolumn{9}{|c|}{ Unmaintained plots versus well-maintained plots (Student $t$ test) } \\
\hline $\mathrm{H}^{\prime}$ & \multicolumn{8}{|c|}{$\mathrm{t}=-4.749 ; \mathrm{df}=74.326 ; \mathrm{p}=9.7 \times 10^{-6} *$} \\
\hline $\mathrm{D}$ & \multicolumn{8}{|c|}{$\mathrm{t}=2.678 ; \mathrm{df}=51.630 ; \mathrm{p}=9.9 \times 10^{-3} *$} \\
\hline \multicolumn{9}{|c|}{ Native versus alien species (Student $t$ test) } \\
\hline $\mathrm{H}^{\prime}$ & \multicolumn{8}{|c|}{$\mathrm{t}=2.151 ; \mathrm{df}=151.840 ; \mathrm{p}=0.033 *$} \\
\hline D & \multicolumn{8}{|c|}{$\mathrm{t}=-3.271 ; \mathrm{df}=150.580 ; \mathrm{p}=1.3 \times 10^{-3} *$} \\
\hline
\end{tabular}

St2 to St 4 see table $1, *=$ significant difference, $n=$ sample size; $n_{\max }=$ maximum abundance; $\mathrm{S}=$ observed species richness; $\mathrm{Mg}=\mathrm{Margalef}$ 's richness index; $\mathrm{D}=$ Simpson's diversity index; $\mathrm{d}=$ =richness ratio; $\mathrm{H}^{\prime}=$ Shannon-Weaver's diversity index; $\mathrm{H}_{\max }=$ Shannon-Weaver's maximum diversity index; J=Pielou's evenness index; $\mathrm{SE}=$ sampling effort; $\mathrm{N}_{1}=$ Hill's diversity number one $=\mathrm{e}^{\mathrm{H}} ; \mathrm{N}_{2}=$ Hill's diversity number two; Hill=Hill's diversity ratio; $\mathrm{I}_{\mathrm{BP}}=$ Berger-Parker's dominance index.

Three species co-dominated the alien species community: Le. orbonalis, Mo. cubrosa and G. acuteangularis. In short, six species co-dominated the global community: $E$. rufomarginata, G. acuteangularis, Le. orbonalis, Mo. cubrosa, Mo. ypsilon and St. sardoa. The individual rarefaction analysis suggested low species richness in native species and the high species richness in unmaintained plots. Based on the development stage of plants, for a standard sample of 4 specimens, insects on St4 plants appeared most diverse $\left[\mathrm{E}\left(\mathrm{S}_{\mathrm{n}=4}\right)=3 \pm 1\right.$ species], followed by those on $\mathrm{St} 3$ plants $\left[\mathrm{E}\left(\mathrm{S}_{\mathrm{n}=4}\right)=2 \pm 1\right.$ species $]$ and those on $\mathrm{St} 2$ plants $\left[\mathrm{E}\left(\mathrm{S}_{\mathrm{n}=4}\right)=2 \pm 0\right.$ species $]$. Based on the cleanliness of plots, for a standard sample of 42 specimens, well-maintained plots appeared less diverse $\left[\mathrm{E}\left(\mathrm{S}_{\mathrm{n}=42}\right)=9 \pm 0\right.$ species $]$ than unmaintained plots $\left[E\left(S_{n=42}\right)=15 \pm 2\right.$ species]. Based on the native range of species, for a standard sample of 46 specimens, Afrotropical native species appeared less diverse $\left[E\left(S_{n=46}\right)=9 \pm 0\right.$ species] than alien species $\left[E\left(S_{n=46}\right)=10 \pm 1\right.$ species]. 


\subsection{Community Structure}

Based on the species composition, a high level of similarity between plant development stages communities was noted, values of the Bray-Curtis dissimilarity index being closed to zero ( $\mathrm{St} 2$ vs. St3: $\mathrm{BC}=0 ; \mathrm{St} 2$ vs. St4: $\mathrm{BC}=0.054$; $\mathrm{St} 3$ vs. $\mathrm{St} 4: \mathrm{BC}=0.106)$. The same conclusion was valid between well-maintained and unmaintained plots communities $(\mathrm{BC}=0.465)$ and between native and non-native species communities $(\mathrm{BC}=0$. $)$.

On the base of AIC values (Table 3 ) and the SAD plotting (Figures 3), the BS model fitted the insect community observed in St2 plants (2 species, deviance: 1.151, model parameter: $x=2 \pm 0$ individuals) and in St 3 plants ( 2 species, deviance: $7.718, x=4 \pm 3$ ). The same result was noted in the native species settlement ( 9 species, $x=5 \pm 1$ individuals). The $\mathrm{Z}$ theoretical model fitted the SAD in St4 plants (deviance: 7.557, scaling normalizing constant: $\mathrm{Q}=143$ individuals, 22 species, linear regression slope: $\gamma=-1.15 \pm 0.07$, Student $t$ test for the slope: $t=16.399, p<0.001$, fractal dimension: $1 / \gamma=0.870$, linear regression ANOVA: $F_{1,20}=369.961, p<0.001$ coefficient of determination: $\mathrm{r}^{2}=0.931$ ), the well-maintained plots community (deviance $0.877, \mathrm{Q}=42$ individuals, 9 species, $\quad \gamma=-1.4 \pm 0.1, \quad \mathrm{t}=12.938, \quad \mathrm{p}<0.001, \quad 1 / \gamma=0.714$, $\left.\mathrm{F}_{1,7}=167.381, \mathrm{p}<0.001, \mathrm{r}^{2}=0.960\right)$, the unmaintained plots community (deviance: $3.831, \mathrm{Q}=113$ individuals, 22 species, $\gamma=-1.12 \pm 0.07, \mathrm{t}=16.611, \mathrm{p}<0.001,1 / \gamma=0.893, \mathrm{~F}_{1,20}=275.932$, $\mathrm{p}<0.001, \mathrm{r}^{2}=0.932$ ), the alien species settlement (deviance: 1.816, $\mathrm{Q}=109$ individuals; 12 species: $\gamma=-1.52 \pm 0.09$, $\mathrm{t}=17.620, \quad \mathrm{p}<0.001, \quad 1 / \gamma=0.658, \quad \mathrm{~F}_{1,11}=310.474, \quad \mathrm{p}<0.001$, $\mathrm{r}^{2}=0.966$ ) and the overall community (deviance: 11.178, $\mathrm{Q}=155$ individuals; 22 species: $\gamma=-1.16 \pm 0.08, \mathrm{t}=14.439$, $\left.\mathrm{p}<0.001,1 / \gamma=0.862, \mathrm{~F}_{1,20}=208.496, \mathrm{p}<0.001, \mathrm{r}^{2}=0.912\right)$. Then the fractal dimension of the distribution of individuals among species was very low.

\subsection{Association and Correlations Between Species}

Overall, the species from the 11 controlled plots, exhibit a positive net association in presence/absence data (Schluter's Variance ratio $\mathrm{VR}=6.208$, W statistic: 68.284 , $\mathrm{df}=11, \mathrm{p}$ $<0.001)$. The Palaearctic native phytophagous Carabidae $B$. crepitans was positively correlated with two species: $C h$. sexpunctata (Kendall tau correlation coefficient: $\tau=0.725$, $\left.\mathrm{p}=1.9 \times 10^{-3}\right)$ and Co. stenoptera $\left(\tau=0.725, \mathrm{p}=1.9 \times 10^{-3}\right)$. The Afrotropica native phytophagous Chrysomelidae Ch. sexpunctata was positively correlated with seven species divided into four Afrotropical native species [two Acrididae species $C i$. compta and Co. stenoptera $\left(\tau=0.720, \mathrm{p}=2.1 \times 10^{-3}\right.$ and $\tau=0.474, \mathrm{p}=0.043$ respectively), the Brentidae $P h$. grenieri $(\tau=0.580, \mathrm{p}=0.013)$, the Pyrrochoridae $D$. volkeri $(\tau=0.580, \mathrm{p}=0.0130)$ and the Tenebrionidae La. villosa $(\tau=0.580, \mathrm{p}=0.013)]$, one Neartic native Sphingidae species Ma. sexta $(\tau=0.580, \mathrm{p}=0.0130)$ and one Palaeartic native Chrysomelidae species $N$. ferruginea $(\tau=0.580, \mathrm{p}=0.013)$. The Afrotropical native phytophagous Acrididae $\mathrm{Ci}$. compta was positively correlated with Co. stenoptera ( $\tau=0.630$, $\mathrm{p}=6.9 \times 10^{-3}$ ) and the Afrotropica native Acrididae $T$. ferruginea $\left(\tau=0.786, \mathrm{p}=7.7 \times 10^{-3}\right)$. The Afrotropical native phytophagous Acrididae Co. stenoptera was positively correlated with the Afrotropical native Acrididae $\mathrm{Pa}$. notatus $(\tau=0.580, \mathrm{p}=0.013)$. The Afrotropica native phytophagous Acrididae $C y$. aeruginosa was positively correlated with $P a$. notatus $(\tau=0.725, \mathrm{p}=0.0130)$. The Neartic native sap-feeding Pentatomidae E. rufomarginata was positively correlated with Co. stenoptera $\left(\tau=0.630, \mathrm{p}=7.0 \times 10^{-3}\right), C y$. aeruginosa $\left(\tau=0.810, \mathrm{p}=5.3 \times 10^{-3}\right)$ and with $(\tau=0.558, \mathrm{p}=0.017)$. D. volkeri was positively correlated with $C i$. compta $(\tau=0.671$, $\left.\mathrm{p}=7.9 \times 10^{-3}\right)$ and with the Neartic native Sphingidae Ma. sexta $\left(\tau=0.620, p=1.9 \times 10^{-5}\right)$. The Holomediteranean to Central American distributed sap-sucking Coreidae $G$. acuteangularis was positively correlated with two Neartic native species [the sap-feeding Pentatomidae Mo. ypsilum $\left(\tau=0.630, \mathrm{p}=7.0 \times 10^{-3}\right)$ and the Sphingidae Ma. sexta $(\tau=0.725$, $\left.\mathrm{p}=1.9 \times 10^{-3}\right)$ ] and with two Afrotropical native species [the Pyrrochoridae D. volkeri $\left(\tau=0.725, \mathrm{p}=1.9 \times 10^{-3}\right)$ and the phytophagous Scutelleridae Sp. annulus $\left(\tau=0.630, \mathrm{p}=7.0 \times 10^{-}\right.$ $\left.{ }^{3}\right)$ ]. The Afrotropical native phytophagous Tenebrionidae $L a$. villosa was positively correlated with six species [Ci. compta $\left(\tau=0.620, \mathrm{p}=7.9 \times 10^{-3}\right)$, D. volkeri $\left(\tau=1.0, \mathrm{p}=1.9 \times 10^{-5}\right), G$. acuteangularis $\left(\tau=0.725, \mathrm{p}=1.9 \times 10^{-3}\right)$, Ma. sexta $(\tau=1.0$, $\left.\mathrm{p}=1.9 \times 10^{-5}\right)$, the Holartic native Tenebionidae St. sardoa $(\tau=0.558, \mathrm{p}=0.017)$ and $T$. ferruginea $\left(\tau=0.671, \mathrm{p}=4.1 \times 10^{-3}\right)$. The Neartic native phytophagous Coreidae Lp. occidentalis was positively correlated with seven species [Co. stenoptera $(\tau=0.581, \mathrm{p}=0.013)$, Cy. aeruginosa $\left(\tau=0.725, \mathrm{p}=1.9 \times 10^{-3}\right), E$. rufomarginata $(\tau=0.558, \mathrm{p}=0.017)$, the Neartic native Pentatomidae Mo. cubrosa $(\tau=0.506, \mathrm{p}=0.010)$, Mo. ypsilum ( $\tau=0.558, \mathrm{p}=0.017)$, Pa. notatus $\left(\tau=1.0, \mathrm{p}=1.9 \times 10^{-5}\right)$ and $T$. ferruginea $\left(\tau=0.671, \mathrm{p}=4.1 \times 10^{-3}\right)$. The Indomalasian native borer Crambidae Le. orbonalis was positively correlated with T. ferruginea $(\tau=0.588, \mathrm{p}=0.012)$. Ma. sexta was positively correlated with $C$ i. compta $\left(\tau=0.620, \mathrm{p}=7.9 \times 10^{-3}\right)$ and with $T$. ferruginea $\left(\tau=0.671, \mathrm{p}=4.1 \times 10^{-3}\right)$. The Neartic native sapfeeding Pentatomidae Mo. cubrosa was positively correlated with five specie [Co. stenoptera $\left(\tau=0.625, \mathrm{p}=7.5 \times 10^{-3}\right), C i$. compta $(\tau=0.597, \mathrm{p}=0.011)$, Mo. ypsilum $(\tau=0.534, \mathrm{p}=0.022)$, Pa. notatus $(\tau=0.506, \mathrm{p}=0.030)$ and $T$. ferruginea $(\tau=0.491$, $\mathrm{p}=0.036)]$. Mo. ypsilum was positively correlated with $P a$. notatus $(\tau=0.558, \mathrm{p}=0.017)$ and with $T$. ferruginea $(\tau=0.693$, $\left.\mathrm{p}=3.0 \times 10^{-3}\right)$. The Palaearctic native phytophagous Chrysomelidae $N$. ferruginea was positively correlated with eight species $\left[C i\right.$. compta $\left(\tau=0.620, \mathrm{p}=7.9 \times 10^{-3}\right)$, D. volkeri $\left(\tau=1.0, \mathrm{p}=1.9 \times 10^{-5}\right)$, G. acuteangularis $\left(\tau=0.725, \mathrm{p}=1.9 \times 10^{-3}\right)$, La. villosa $\left(\tau=1.0, \mathrm{p}=1.9 \times 10^{-5}\right)$, Ma. sexta $\left(\tau=1.0, \mathrm{p}=1.9 \times 10^{-5}\right)$, Ph. grenieri $\left(\tau=1.0, \mathrm{p}=1.9 \times 10^{-5}\right)$, St. sardoa $(\tau=0.558$, $\mathrm{p}=0.017)$ and $T$. ferruginea $\left.\left(\tau=0.671, \mathrm{p}=4.1 \times 10^{-3}\right)\right]$. The Afrotropical native phytophagous Acrididae $\mathrm{Pa}$. notatus was positively correlated with $T$. ferruginea $\left(\tau=0.671, \mathrm{p}=4.1 \times 10^{-3}\right)$. The Palaearctic distributed phytophagous Carabaeidae Pr. cuprea was positively correlated with 10 species [Ch. sexpunctata $(\tau=0.581, \mathrm{p}=0.017), \quad$ Ci. compta $(\tau=0.620$, $\left.\mathrm{p}=7.9 \times 10^{-3}\right), \quad$ D. volkeri $\left(\tau=1.0, \quad \mathrm{p}=1.9 \times 10^{-5}\right), \quad G$. acuteangularis $\left(\tau=0.725, \mathrm{p}=1.9 \times 10^{-3}\right)$, La. villosa $(\tau=1.0$, $\left.\mathrm{p}=1.9 \times 10^{-5}\right)$, Ma. sexta $\left(\tau=1.0, \mathrm{p}=1.9 \times 10^{-5}\right), N$. ferruginea 
$\left(\tau=1.0, \mathrm{p}=1.9 \times 10^{-5}\right)$, Ph. grenieri $\left(\tau=1.0, \mathrm{p}=1.9 \times 10^{-5}\right)$, St. sardoa $(\tau=0.558, \mathrm{p}=0.017)$ and $T$. ferruginea $(\tau=0.671$, $\left.\left.\mathrm{p}=4.1 \times 10^{-3}\right)\right] . P h$. grenieri was positively correlated with six species [Ci. compta $\left(\tau=0.620, \mathrm{p}=7.9 \times 10^{-3}\right)$, D. volkeri $(\tau=1.0$, $\left.\mathrm{p}=1.9 \times 10^{-5}\right), G$. acuteangularis $\left(\tau=0.725, \mathrm{p}=1.9 \times 10^{-3}\right)$, La. villosa $\left(\tau=1.0, \mathrm{p}=1.9 \times 10^{-5}\right)$, Ma. $\operatorname{sexta}\left(\tau=1.0, \mathrm{p}=1.9 \times 10^{-5}\right)$ and St. sardoa $(\tau=0.558, \mathrm{p}=0.017)]$. The Holartic to Palaearctic distributed phytophagous Chrysomelidae Se. halensis was positively correlated with four species [Le. orbonalis ( $\tau=0.490, \mathrm{p}=0.036)$, Lp. occidentalis $\left(\tau=0.671, \mathrm{p}=4.1 \times 10^{-3}\right)$, Mo. cubrosa $(\tau=0.491, \mathrm{p}=0.036)$ and Pa. notatus $(\tau=0.671$, $\left.\left.\mathrm{p}=4.1 \times 10^{-3}\right)\right]$. The Palaearctic native phytophagous Tenebrionidae St. sardoa was positively correlated with $D$. volkeri $(\tau=0.558, \mathrm{p}=0.017)$ and with Ma. sexta $(\tau=0.558$, $\mathrm{p}=0.017$ ). Apart from these significant correlations, the other correlations were not significant (Table 4). After treatments of the crop plots with chemical pesticides, some species of alien species were positively correlated with other non-native species and with a few native ones.

\subsection{Damages on the Aerial Organs of Plants}

Despite chemical treatment using insecticides, high percentage of destroyed aerial plant organs were recorded $(30.3 \%$ of scarified stems, $20.0 \%$ of nibbled leaves, $30.6 \%$ of nibbled flowers and $36.6 \%$ of drilled fruits; Table 5). Attacks of plants by phytophagous insects is probably due to insect from nearby untreated fallows, or to insects that have escaped the chemical pesticides, because hidden in microhabitats inaccessible by the chemicals (case of insects with hypogeal larvae developing in the soil), or the cleaning of the treated plants by rainwater. Stems and fruits with black scars suggested the point of drilling and thus were damaged by borer larvae. The borehole was scarred when the boring larva was still lodged in the stem or the fruit, or opened when the larvae has left the host stem or fruit. Infested fruits were unfit for consumption and marketing and therefore constituted a loss for the gardener. A total of 163,524 specimens of plant organs (1.5\% stems, $88.0 \%$ leaves, $7.1 \%$ flowers and 3.3\% fruits) were surveyed in 11 plots of eggplant plants. Stems and fruits were drilled (30.3\% and $36.6 \%$ respectively) (Table $5 \mathrm{~A}$ and $5 \mathrm{D}$ ). Flowers and leaves were seriously nibbled or perforated $(30.6 \%$ and $20.0 \%$ respectively) (Table 5B and 5C). The low percentage of damage (1.1\% from St2 plants) and the very high percentage of destruction (25.5\% on St 4 plants) were recorded on stems. Pairwise comparison showed in all cases a significant difference between the three plant development stages. In all cases, percentages of the damaged plant organs were significantly high in unmaitained plots than that recorded in well-maintained plots (Table 5). Although the percentage of damaged organs was significantly lower than the percentage of healthy organs, the health of the eggplant plants and their photosynthetic potential remained largely affected. Note that to the influence of harmful insects is very often added limiting effect of soil water content, soil fertility and effect of several plant pathogens such as viruses, microscopic fungi for rotting and the action of pathogenic bacteria.

Of the 2,468 stems checked, 747 stems (30.3\%) were punctured at the plant's ramifications or branches. A total of 413 damaged stems or $16.7 \%$ were from unmaintained plots and 334 stems or $13.5 \%$ from well-maintained plots. The damage rate was significantly low in well-maintained plots than in unmaintained plots (Table 5A). Damage on stems was characterized by perforations by borer insects whose larvae consume the plant's internal tissues. The number of perforations varied from 1 to 10 ( $3 \pm 1$ perforations, 413 stems $)$ in unmaintained plots and 1 to 5 ( $2 \pm 1$ perforations, 334 stems) in well-maintained plots. Attacks of the stems usually resulted in the death of the young plants or the death of the apical part of the bored branch. In each type of plot, the number of bored stems was significantly low when compared to the number of healthy stems.

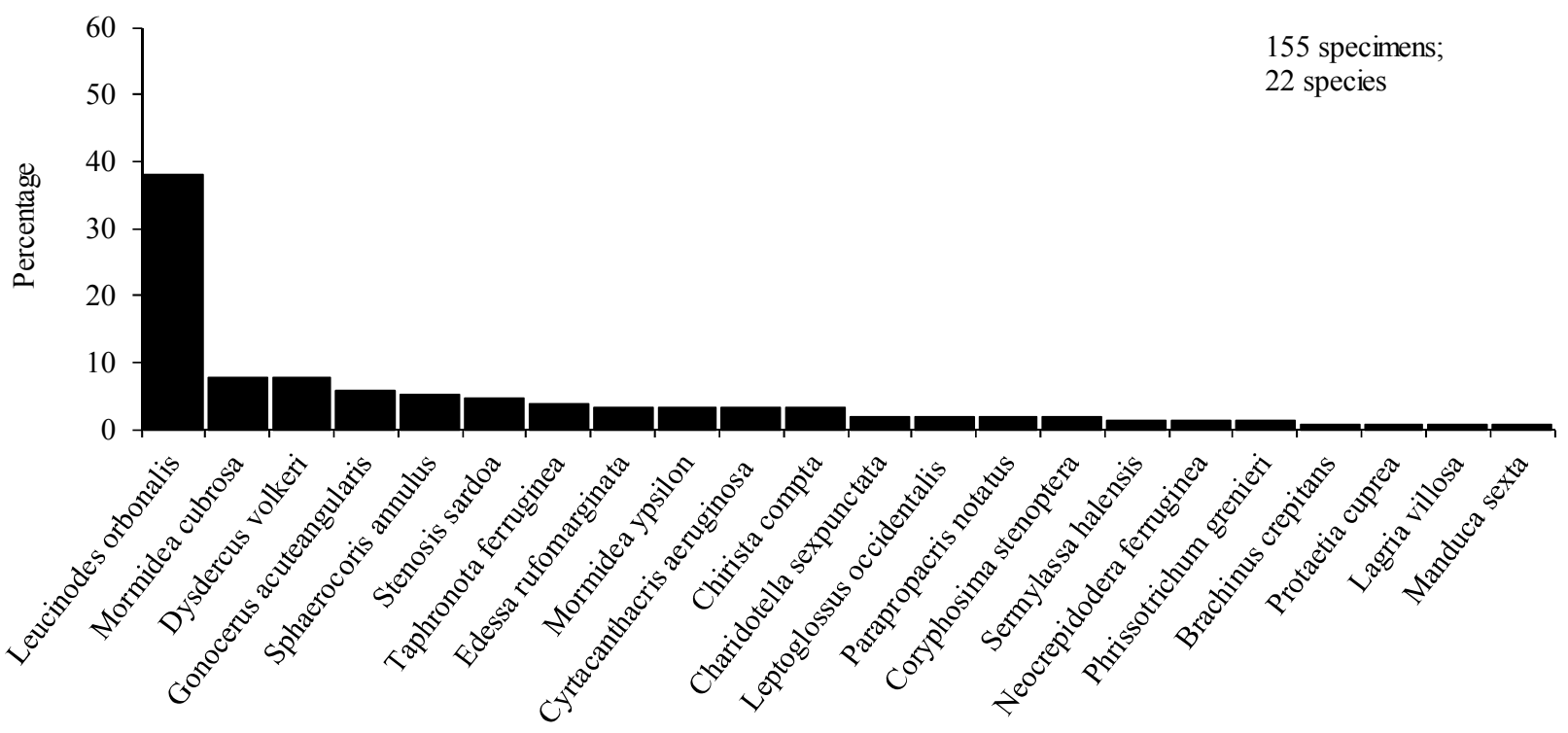

Figure 2. Rank-frequency diagram of the total collected insects showing species in decreasing order of numerical dominance. 

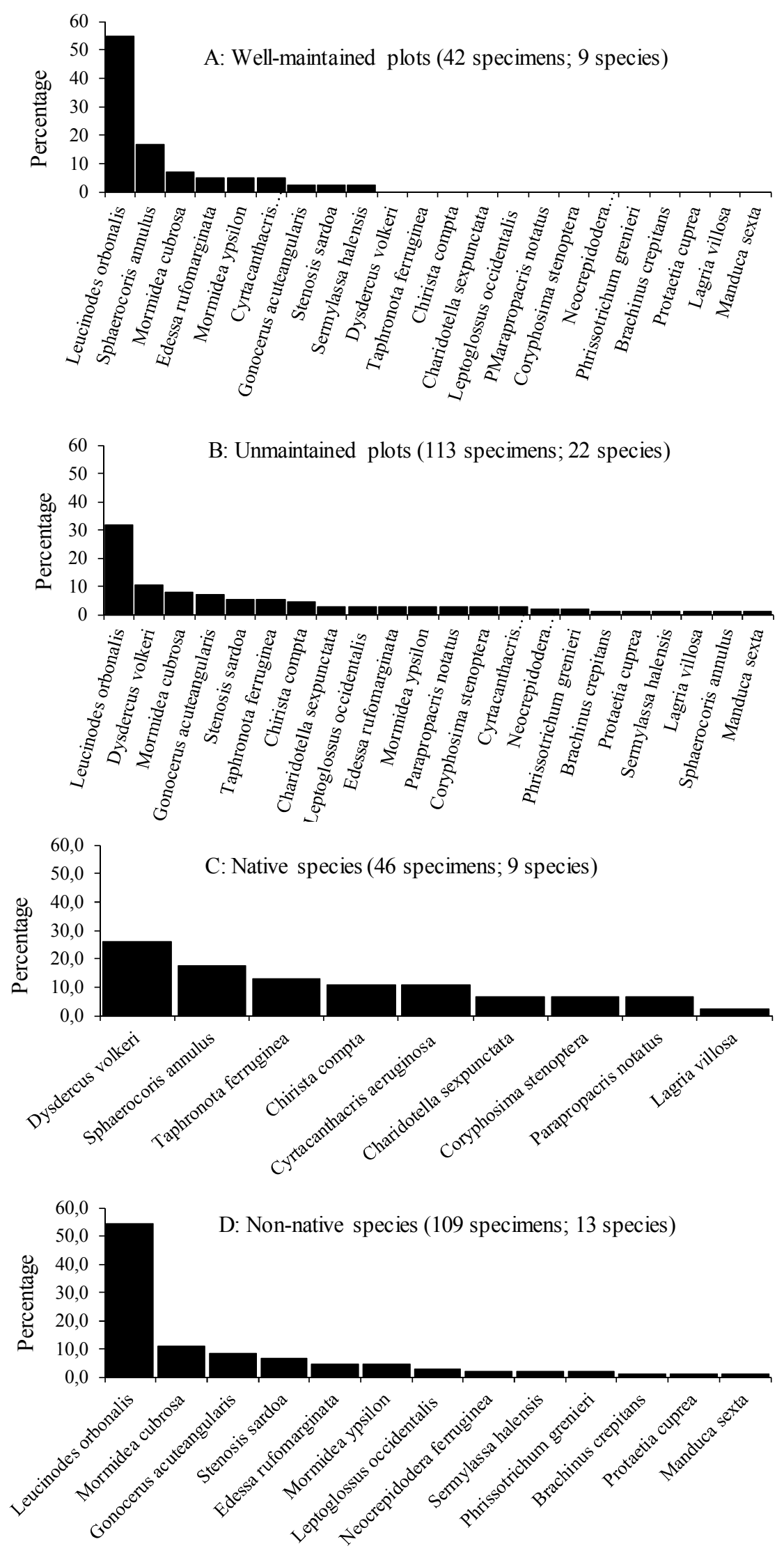

Figure 3. Rank-frequency diagrams of relative insect species abundances collected from five development stages of potato plants. For each development stage percentages were calculated on the total number of individuals collected. 
Table 3. Akaike Information Criteria (AIC) and Bayesian Information Criteria (BIC) values for the adjusted theoretical models.

\begin{tabular}{|c|c|c|c|c|c|c|c|c|}
\hline \multirow[b]{2}{*}{$\begin{array}{l}\text { SAD theoretical } \\
\text { models }\end{array}$} & \multicolumn{8}{|c|}{ AIC values and the best fitted theoretical model } \\
\hline & $\begin{array}{l}\mathrm{St2} \\
\mathrm{S}=2 \\
\mathrm{n}=4\end{array}$ & $\begin{array}{l}\mathrm{St3} \\
\mathrm{S}=2 \\
\mathrm{n}=8\end{array}$ & $\begin{array}{l}\text { St4 } \\
S=22 \\
n=143\end{array}$ & $\begin{array}{l}\text { Well-maintained } \\
S=9 \\
n=42\end{array}$ & $\begin{array}{l}\text { Unmaintained } \\
S=22 \\
n=113\end{array}$ & $\begin{array}{l}\text { Native species } \\
S=9 \\
n=46 \text { (BIC) }\end{array}$ & $\begin{array}{l}\text { Non-native } \\
\mathrm{S}=13 \\
\mathrm{n}=109 \text { (BIC) }\end{array}$ & $\begin{array}{l}\text { Global } \\
S=22 \\
n=155\end{array}$ \\
\hline Broken-stick & $6.38 *$ & $6.58 *$ & 106.11 & 37.45 & 86.58 & $33.61(33.61) *$ & 69.68 & 115.15 \\
\hline Log-linear & 8.00 & 7.81 & 110.91 & 35.41 & 90.95 & $33.61(33.80)$ & 57.74 & 120.97 \\
\hline Log-normal & 9.23 & 9.81 & 87.72 & 33.84 & 77.85 & 34.54 & $48.68(49.65)$ & 92.91 \\
\hline Zipf & 9.23 & 9.81 & $82.08 *$ & $30.50 *$ & $74.55 *$ & 35.53 & $48.00(48.97) *$ & $86.96 *$ \\
\hline Zipf-Mandelbroot & NA & NA & 84.08 & 32.50 & 76.55 & 37.00 & 49.90 & 88.96 \\
\hline
\end{tabular}

SAD: Species Abundance Distribution, St2 to St4 see table 1, BIC: Bayesian Information Criteria, S: species richness, $\mathrm{n}=$ sample size, $*$ the best fitted theoretical model of the species abundance distribution, NA: Not available

Of the 143,915 leaves inspected, 27,283 leaves $(18.9 \%)$ were perforated by phytophagous insects. The number of perforations varied from one to 80 (12 \pm 1 perforations, 10,993 leaves) in unmaintained plots and two to $100(11 \pm 1$ perforations, 16,290 leaves) in well-maintained plots. In each plot, the number of damaged leaves was low when compared to the healthy leaves. The percentage of damaged leaves was high in unmaintained plots than well-maintained plots (Table $5 \mathrm{~B})$. The numbers of damaged leaves varied between unmaintained and well-maintained plots (Table 5B).

Of the 11,694 flower buds and flowers inspected in the 11 plots $(4,003$ flowers or $34.3 \%$ from unmaintained plots and 7,671 flower buds and flowers or $65.7 \%$ from wellmaintained plots), 3,576 flower buds and flowers (30.6\%) were damaged by phytophagous insects. The damage rate was significantly low in unmaintained plots $(1,591$ flower buds and flowers: 13.6\%) than in well-maintained plots (1,985 flower buds and flowers: 17.0\%) (Table 5C). Many damaged flowers aborted and dropped to the ground.

Fruits with black scars suggested points of drilling by borer larvae. The borehole was scarred when the borer larva is still lodged, or opened when the larva has left the fruit. Damaged fruits were unfit for consumption and marketing and constituted a loss for the gardener. Of the 5,467 fruits $(3,196$ fruits i.e. $58.5 \%$ from unmaintained plots and 2,271 fruits i.e $41.5 \%$ from well-maintained plots), we noted that 2,166 fruits $(36.6 \%)$ were damaged [1,357 (24.8\%) and $809(14.8 \%)$ damaged fruits from unmaintained and well-maintained plots respectively]. The number of damaged fruits was low compared to healthy fruits (Table 5D). The percentage of damaged fruits was high in unmaintained plots $(24.8 \%)$ than well-maintained plots (14.8\%) (Table 5D). Of the 2,166 damaged fruits, Cat 1 fruits were more attacked $(49.1 \%)$ than Cat2 and Cat3 fruits (23.5\% and $27.4 \%$ respectively, Table 5E). The percentage difference of damaged fruits in Cat2 and Cat3 fruits was significant (Fisher exact test: $\chi^{2}=36.95$, $\left.\mathrm{p}=1.5 \times 10^{-9}\right)$.

\section{Discussion}

\subsection{Species Richness, Abundance and Dominance}

Our studies revealed the presence of 23 species, 22 genera, 14 families and four orders associated with eggplant plants.
Based on the field collection, Lepidoptera represented more than $38.7 \%$ of the pest insects sampled while Hemiptera and Orthoptera represented respectively $34.7 \%$ and $14.1 \%$ of sampled insects and lastly Coleoptera represented $12.1 \%$ of the collected insects. These insect are frequently reported as pests in market gardens in several countries $[1,28,99,100]$. The peculiarity of our results is that they are active on plants two weeks after the insecticide treatments were stopped, suggesting either the re-colonization of the fields from the neighbouring untreated fallows, or the cleaning of aerial plant organs by rainwater, or an appearance of individuals resistant to insecticides.

Resistance would have been developed as a consequence of anarchic and uncontrolled use of pesticides by undereducated farmers of the locality [17, 32-34]. Ph. grenieri (Coleoptera: Brentidae) was the main stem borer and Le. orbonalis (Lepidoptera: Crambidae) was the main fruit borer. Phytophagous and sap-feeding pests [Hemiptera Coreidae (7.7\%), Pentatomidae (3.2\%), Pyrrhocoridae (7.7\%), Scutelleridae (5.2\%), Orthoptera Pyrgomorphidae (3.9\%), Coleoptera Tenebrionidae $(0.6 \%)$, Lepidoptera Crambidae (38.1\%) and Sphingidae (0.6\%)], cumulatively represented $67.0 \%$ of the collection. The results were contrary to those reported in potato fields in Indonesia [101], eggplant fields in Bangladesh [29, 30] and other market garden plants in Cameroon [23, 31], where the order Homoptera Aphididae was most abundant. In the locality of Balessing (Cameroon), the species richness of insects associated with eggplant, was quite close to the observations made by several authors in untreated plots. For illustration, in Sudan, 28 pest species that damage untreated eggplant fields are divided into 18 phytophagous species, seven species that destroy flowers and fruits, three stem-borers and root-borer species [29]. Similarly in Bangladesh, 20 species that damage eggplant plants are divided into 15 phytophagous species, three pest species of flowers and fruits and two borer species [29]. Our works also show that Le. orbonalis (Lepidoptera: Crambidae) was abundant and the most destructive of fruits. This result is in agreement with that of Srinivasan [12] who reported the dominance of this Lepidoptera in eggplant crops in Taiwan. Le. orbonalis is an oligophagous pest that attacks leaves and fruits of Solanaceae plants [102]. 
Table 4. Kendall tau correlation between insect species associated with eggplant plants in 11 plots.

\begin{tabular}{|c|c|c|c|c|c|c|c|}
\hline Species 1 / species 2 & Tau & Species 1 / species 2 & Tau & Species 1 / species 2 & Tau & Species 1 / species 2 & Tau \\
\hline Brachinus crepitans / & & Co. stenoptera / & & E. rufomarginata & & Ma. sexta/ & \\
\hline Charidotella sexpunctata & $0.725 *$ & D. volkeri & $-0,145 \mathrm{~ns}$ & Se. halensis & $0,277 \mathrm{~ns}$ & Ph. grenieri & $1.000 *$ \\
\hline Chirista compta & $0,434 \mathrm{~ns}$ & E. rufomarginata & $0.630 *$ & E. rufomarginata & & Pr. cuprea & $1.000 *$ \\
\hline Coryphosima stenoptera & $0.725 *$ & G. acuteangularis & $-0,211 \mathrm{~ns}$ & Sp. annulus & $-0,346 \mathrm{~ns}$ & Se. halensis & $-0,149 \mathrm{~ns}$ \\
\hline Cyrtacanthacris aeruginosa & $-0,145 \mathrm{~ns}$ & La. villosa & $-0,145 \mathrm{~ns}$ & St. sardoa & $-0,346 \mathrm{~ns}$ & Ma. sexta/ & \\
\hline Dysdercus volkeri & $-0.100 \mathrm{~ns}$ & Le. orbonalis & $0,255 \mathrm{~ns}$ & T. ferruginea & $0,277 \mathrm{~ns}$ & Sp. annulus & $0,434 \mathrm{~ns}$ \\
\hline Gonocerus acuteangularis & $-0,145 \mathrm{~ns}$ & Ma. sexta & $-0,145 \mathrm{~ns}$ & La. villosa & $0.725 *$ & T. ferruginea & $0.671 *$ \\
\hline Lagria villosa & $-0.100 \mathrm{~ns}$ & Mo. cubrosa & $0.625 *$ & Le. orbonalis & $0.000 \mathrm{~ns}$ & Mo. cubrosa / & \\
\hline Leucinodes orbonalis & $-0,044 \mathrm{~ns}$ & Mo. ypsilon & $0,225 \mathrm{~ns}$ & Lp. occidentalis & $-0,145 \mathrm{~ns}$ & Mo. ypsilon & $0.534 *$ \\
\hline Leptoglossus occidentalis & $-0.100 \mathrm{~ns}$ & N. ferruginea & $-0,145 \mathrm{~ns}$ & Ma. sexta & $0.725 *$ & N. ferruginea & $0,152 \mathrm{~ns}$ \\
\hline Manduca sexta & $-0.100 \mathrm{~ns}$ & Pa. notatus & $0.581 *$ & Mo. cubrosa & $0,220 \mathrm{~ns}$ & Pa. notatus & $0.506 *$ \\
\hline Mormidea cubrosa & $0,405 \mathrm{~ns}$ & Ph. grenieri & $-0,145 \mathrm{~ns}$ & Mo. ypsilon & $0.630 *$ & Ph. grenieri & $0,152 \mathrm{~ns}$ \\
\hline Mo. ypsilon & $-0,186 \mathrm{~ns}$ & Pr. cuprea & $-0,145 \mathrm{~ns}$ & N. ferruginea & $0.725 *$ & Pr. cuprea & $0,152 \mathrm{~ns}$ \\
\hline Parapropacris notatus & $-0.100 \mathrm{~ns}$ & Sp. annulus & $-0,270 \mathrm{~ns}$ & Ph. grenieri & $0.725 *$ & Sp. annulus & $0,283 \mathrm{~ns}$ \\
\hline Phrissotrichum grenieri & $-0.100 \mathrm{~ns}$ & St. sardoa & $-0,270 \mathrm{~ns}$ & Pr. cuprea & $0.725 *$ & St. sardoa & $-0,251 \mathrm{~ns}$ \\
\hline Protaetia cuprea & $-0.100 \mathrm{~ns}$ & T. ferruginea & $0,324 \mathrm{~ns}$ & Se. halensis & $-0,216 \mathrm{~ns}$ & T. ferruginea & $0.491 *$ \\
\hline Sermylassa halensis & $-0,149 \mathrm{~ns}$ & Cy. aeruginosa / & & Sp. annulus & $0.630 *$ & Mo. ypsilon / & \\
\hline Sphaerocoris annulus & $-0,186 \mathrm{~ns}$ & D. volkeri & $-0,145 \mathrm{~ns}$ & St. sardoa & $0,315 \mathrm{~ns}$ & N. ferruginea & $0.372 \mathrm{~ns}$ \\
\hline Stenosis sardoa & $-0,186 \mathrm{~ns}$ & E. rufomarginata & $0.810 *$ & T. ferruginea & $0,433 \mathrm{~ns}$ & Pa. notatus & $0.558 *$ \\
\hline Taphronota ferruginea & $-0,149 \mathrm{~ns}$ & G. acuteangularis & $-0,211 \mathrm{~ns}$ & La. villosa/ & & Ph. grenieri & $0.372 \mathrm{~ns}$ \\
\hline Ch. sexpunctata / & & La. villosa & $-0,145 \mathrm{~ns}$ & Le. orbonalis & $0.651 \mathrm{~ns}$ & Pr. cuprea & $0,372 \mathrm{~ns}$ \\
\hline Ci. compta & $0.720 *$ & Le. orbonalis & $0,064 \mathrm{~ns}$ & Lp. occidentalis & $-0.100 \mathrm{~ns}$ & Se. halensis & $0,277 \mathrm{~ns}$ \\
\hline Co. stenoptera & $0.674 *$ & Lp. occidentalis & $0.725 *$ & Ma. sexta & $1.000 *$ & Sp. annulus & $0,385 \mathrm{~ns}$ \\
\hline Cy. aeruginosa & $-0,211 \mathrm{~ns}$ & Ma. sexta & $-0,145 \mathrm{~ns}$ & Mo. cubrosa & $0,152 \mathrm{~ns}$ & St. sardoa & $0,038 \mathrm{~ns}$ \\
\hline D. volkeri & $0.580 *$ & Mo. cubrosa & $0,184 \mathrm{~ns}$ & Mo. ypsilon & $0,277 \mathrm{~ns}$ & T. ferruginea & $0.693 *$ \\
\hline E. rufomarginata & $0,180 \mathrm{~ns}$ & Mo. ypsilon & $0,315 \mathrm{~ns}$ & N. ferruginea & $1.000 *$ & N. ferruginea / & \\
\hline Le. orbonalis & $0,191 \mathrm{~ns}$ & Ph. grenieri & $-0,145 \mathrm{~ns}$ & Pr. cuprea & $1.000 *$ & Pr. cuprea & $1.000 *$ \\
\hline Lp. occidentalis & $-0.145 \mathrm{~ns}$ & Pr. cuprea & $-0,145 \mathrm{~ns}$ & Se. halensis & $-0,149 \mathrm{~ns}$ & Se. halensis & $-0,149 \mathrm{~ns}$ \\
\hline Ma. sexta & $0.580 *$ & Se. halensis & $0,432 \mathrm{~ns}$ & Sp. annulus & $0.434 \mathrm{~ns}$ & Sp. annulus & $0.434 \mathrm{~ns}$ \\
\hline Mo. cubrosa & $0,441 \mathrm{~ns}$ & Sp. annulus & $-0,270 \mathrm{~ns}$ & St. sardoa & $0.558 *$ & St. sardoa & $0.558 *$ \\
\hline Mo. ypsilon & $0,090 \mathrm{~ns}$ & St. sardoa & $-0,270 \mathrm{~ns}$ & T. ferruginea & $0.671 *$ & T. ferruginea & $0.671 *$ \\
\hline N. ferruginea & $0.580 *$ & T. ferruginea & $0,433 \mathrm{~ns}$ & Le. orbonalis / & & Pa. notatus/ & \\
\hline Pa. notatus & $-0,145 \mathrm{~ns}$ & D. volkeri/ & & Lp. occidentalis & $0.439 \mathrm{~ns}$ & Ph. grenieri & $-0.100 \mathrm{~ns}$ \\
\hline Ph. grenieri & $0.580 *$ & E. rufomarginata & $-0.186 \mathrm{~ns}$ & Ma. sexta & $0,351 \mathrm{~ns}$ & Pr. cuprea & $-0.100 \mathrm{~ns}$ \\
\hline Pr. cuprea & $0.580 *$ & G. acuteangularis & $0.725 *$ & Mo. cubrosa & $0.466 \mathrm{~ns}$ & Se. halensis & $0.671 *$ \\
\hline Se. halensis & $-0,216 \mathrm{~ns}$ & La. villosa & $1.000 *$ & Mo. ypsilon & $0.245 \mathrm{~ns}$ & Sp. annulus & $-0.186 \mathrm{~ns}$ \\
\hline Sp. annulus & $0.135 \mathrm{~ns}$ & Le. orbonalis & $0.351 \mathrm{~ns}$ & N. ferruginea & $0,351 \mathrm{~ns}$ & St. sardoa & $-0.186 \mathrm{~ns}$ \\
\hline St. sardoa & $0,225 \mathrm{~ns}$ & Lp. occidentalis & $-0.100 \mathrm{~ns}$ & Pa. notatus & $0,439 \mathrm{~ns}$ & T. ferruginea & $0.671 *$ \\
\hline T. ferruginea & $0,324 \mathrm{~ns}$ & Ma. sexta & $0.620 *$ & Ph. grenieri & $0.351 \mathrm{~ns}$ & Ph. grenieri/ & \\
\hline Ci. compta/ & & Mo. cubrosa & $0.152 \mathrm{~ns}$ & Pr. cuprea & $0,351 \mathrm{~ns}$ & Pr. cuprea & $1.000 *$ \\
\hline Co. stenoptera & $0.630 *$ & Mo. ypsilon & $0.372 \mathrm{~ns}$ & Se. halensis & $0.490 *$ & Se. halensis & $-0.149 \mathrm{~ns}$ \\
\hline Cy. aeruginosa & $0,225 \mathrm{~ns}$ & N. ferruginea & $1.000 *$ & Sp. annulus & $0.109 \mathrm{~ns}$ & Sp. annulus & $0.434 \mathrm{~ns}$ \\
\hline D. volkeri & $0.671 *$ & Pa. notatus & $-0.100 \mathrm{~ns}$ & St. sardoa & $0.000 \mathrm{~ns}$ & St. sardoa & $0.558 *$ \\
\hline E. rufomarginata & $0.385 \mathrm{~ns}$ & Ph. grenieri & $1.000 *$ & T. ferruginea & $0.588 *$ & T. ferruginea & $0.671 *$ \\
\hline G. acuteangularis & $0.360 \mathrm{~ns}$ & Pr. cuprea & $1.000 *$ & Lp. occidentalis / & & Pr. cuprea/ & \\
\hline La. villosa & $0.620 *$ & Se. halensis & $-0,149 \mathrm{~ns}$ & Ma. sexta & $-0,100 \mathrm{~ns}$ & Se. halensis & $-0,149 \mathrm{~ns}$ \\
\hline Le. orbonalis & $0.462 \mathrm{~ns}$ & Sp. annulus & $0.434 \mathrm{~ns}$ & Mo. cubrosa & $0.506 *$ & Sp. annulus & $0,434 \mathrm{~ns}$ \\
\hline Lp. occidentalis & $0.434 \mathrm{~ns}$ & St. sardoa & $0.558 *$ & Mo. ypsilon & $0.558 *$ & St. sardoa & $0.558 *$ \\
\hline Ma. sexta & $0.620 *$ & T. ferruginea & $0.671 *$ & N. ferruginea & $-0.100 \mathrm{~ns}$ & T. ferruginea & $0.671 *$ \\
\hline Mo. cubrosa & $0.597 *$ & E. rufomarginata & & Pa. notatus & $1.000 *$ & Se. halensis / & \\
\hline Mo. ypsilon & $0.462 \mathrm{~ns}$ & G. acuteangularis & $-0,270 \mathrm{~ns}$ & Ph. grenieri & $-0.100 \mathrm{~ns}$ & Sp. annulus & $-0.278 \mathrm{~ns}$ \\
\hline N. ferruginea & $0.620 *$ & La. villosa & $-0,186 \mathrm{~ns}$ & Pr. cuprea & $-0.100 \mathrm{~ns}$ & St. sardoa & $-0.277 \mathrm{~ns}$ \\
\hline Pa. notatus & $0,434 \mathrm{~ns}$ & Le. orbonalis & $0.000 \mathrm{~ns}$ & Se. halensis & $0.671 *$ & T. ferruginea & $0.389 \mathrm{~ns}$ \\
\hline
\end{tabular}




\begin{tabular}{|c|c|c|c|c|c|c|c|}
\hline Species 1 / species 2 & Tau & Species 1 / species 2 & Tau & Species 1 / species 2 & Tau & Species 1 / species 2 & Tau \\
\hline Ph. grenieri & $0.620 *$ & Lp. occidentalis & $0.558 *$ & Sp. annulus & $-0,186 \mathrm{~ns}$ & Sp. annulus / & \\
\hline Ci. compta/ & & Ma. sexta & $-0,186 \mathrm{~ns}$ & St. sardoa & $-0,186 \mathrm{~ns}$ & St. sardoa & $0.077 \mathrm{~ns}$ \\
\hline Pr. cuprea & $0.620 *$ & Mo. cubrosa & $0.377 \mathrm{~ns}$ & T. ferruginea & $0.671 *$ & T. ferruginea & $0.185 \mathrm{~ns}$ \\
\hline Se. halensis & $0.185 \mathrm{~ns}$ & Mo. ypsilon & $0,154 \mathrm{~ns}$ & Ma. sexta/ & & St. sardoa / & \\
\hline Sp. annulus & $0.115 \mathrm{~ns}$ & N. ferruginea & $-0,186 \mathrm{~ns}$ & Mo. cubrosa & $0,152 \mathrm{~ns}$ & T. ferruginea & $0,277 \mathrm{~ns}$ \\
\hline St. sardoa & $0.192 \mathrm{~ns}$ & Pa. notatus & $0.558 *$ & Mo. ypsilon & $0,372 \mathrm{~ns}$ & & \\
\hline T. ferruginea & $0.786 *$ & Ph. grenieri & $-0,186 \mathrm{~ns}$ & N. ferruginea & $1.000 *$ & & \\
\hline Су. aeruginosa & $0,368 \mathrm{~ns}$ & Pr. cuprea & $-0,186 \mathrm{~ns}$ & Pa. notatus & $-0.100 \mathrm{~ns}$ & & \\
\hline
\end{tabular}

ns: not significant correlation ( $\mathrm{p}$-value $>0.05$ ), *: significant correlation ( $\mathrm{p}$-value $<0.05$ )

Table 5. Percentage of healty and damaged aerial organs of eggplant plants.

\begin{tabular}{|c|c|c|c|c|c|c|c|c|}
\hline & \multicolumn{4}{|l|}{ A. Stems } & \multicolumn{4}{|l|}{ B. Leaves } \\
\hline & Healty (\%) & Damaged (\%) & Total (\%) & p-value & Healty (\%) & Damaged (\%) & Total (\%) & p-value \\
\hline St2 plants & $323(13.1)$ & $27(1.1)$ & $350(14.2)$ & $\mathrm{p}<0.001^{*}$ & $9,874(6.9)$ & $1,992(1.4)$ & $11,866(8.2)$ & $\mathrm{p}<0.001^{*}$ \\
\hline St3 plants & $301(12.2)$ & $90(3.6)$ & $391(15.8)$ & $\mathrm{p}<0.001 *$ & $24,648(17.1)$ & $2,900(2.0)$ & $27,548(19.1)$ & $\mathrm{p}<0.001^{*}$ \\
\hline St4 plants & $1,097(44.4)$ & $630(25.5)$ & $1,727(70.0)$ & $\mathrm{p}<0.001 *$ & $82,110(57.1)$ & $22,391(15.6)$ & $104,501(72.6)$ & $\mathrm{p}<0.001^{*}$ \\
\hline Global & $1,721(69.7)$ & $747(30.3)$ & $2,468(100.0)$ & $\mathrm{p}<0.001 *$ & $116,632(81)$ & $27,283(18.9)$ & $143,915(100.0)$ & $\mathrm{p}<0.001^{*}$ \\
\hline I & $1,164(47.2)$ & $334(13.5)$ & $1,498(60.7)$ & $\mathrm{p}<0.001^{*}$ & $84,979(59.0)$ & $16,290(11.3)$ & $101,269(70.4)$ & $\mathrm{p}<0.001^{*}$ \\
\hline II & $557(22.6)$ & $413(16.7)$ & $970(39.3)$ & $\mathrm{p}<0.001 *$ & $31,653(22.0)$ & $10,993(7.6)$ & $42,646(29.6)$ & $\mathrm{p}<0.001^{*}$ \\
\hline \multirow[t]{3}{*}{ Comparison } & \multicolumn{4}{|c|}{$\begin{array}{l}\text { Fisher exact test }(\mathrm{I} v s . \mathrm{II}): \\
\text { Healthy stems: } \chi^{2}=437.27, \mathrm{df}=1, \mathrm{p}=7.9 \times 10^{-97} * \\
\text { Damaged stems: } \chi^{2}=16.72, \mathrm{df}=1, \mathrm{p}=5.4 \times 10^{-5} *\end{array}$} & \multicolumn{4}{|c|}{$\begin{array}{l}\text { Fisher exact test (I vs. II): } \\
\text { Healthy leaves: } \chi^{2}=50,622.0, \mathrm{df}=1, \mathrm{p}<0.001^{*} \\
\text { Damaged leaves: } \chi^{2}=20,699.0, \mathrm{df}=1, \mathrm{p}<0.001^{*}\end{array}$} \\
\hline & \multicolumn{4}{|c|}{ C. Flower buds and flowers } & \multicolumn{4}{|l|}{ D. Fruits } \\
\hline & Healty (\%) & Damaged (\%) & Total (\%) & p-value & Healty (\%) & Damaged (\%) & Total (\%) & p-value \\
\hline St2 plants & 1,591 (13.6) & $191(1.6)$ & $1,782(15.3)$ & $\mathrm{p}<0.001 *$ & - & - & - & - \\
\hline St3 plants & $3,044(26.1)$ & 1,298 (11.1) & $4,342(37.2)$ & $\mathrm{p}<0.001 *$ & - & - & - & - \\
\hline St4 plants & $3,463(29.7)$ & $2,087(17.9)$ & $5,550(47.5)$ & $\mathrm{p}<0.001 *$ & $3,301(60.4)$ & $2,166(36.6)$ & $5,467(100.0)$ & $\mathrm{p}<0.001^{*}$ \\
\hline Global & $8,098(69.4)$ & $3,576(30.6)$ & $11,674(100.0)$ & $\mathrm{p}<0.001 *$ & $3,301(60.4)$ & $2,166(36.6)$ & $5,467(100.0)$ & $\mathrm{p}<0.001^{*}$ \\
\hline I & 5,686 (48.7) & $1,985(17.0)$ & $7,671(65.7)$ & $\mathrm{p}<0.001 *$ & $1,462(26.7)$ & $809(14.8)$ & $2,271(41.5)$ & $p<0.001^{*}$ \\
\hline & $2,412(20.7)$ & 1,591 (13.6) & $4,003(34.3)$ & $\mathrm{p}<0.001 *$ & 1,839 (33.7) & $1,357(24.8)$ & $3,196(58.5)$ & $\mathrm{p}<0.001^{*}$ \\
\hline Comparison & \multicolumn{4}{|c|}{$\begin{array}{l}\text { Fisher-Freedman-Halton test (St2, St3 and St4): } \\
\chi^{2}=2068, \mathrm{df}=2, \mathrm{p}<0.001 * \\
\text { Fisher exact test }(\mathrm{I} v \mathrm{I} \text {. II): } \\
\text { Healthy flowers: } \chi^{2}=1,062.6, \mathrm{df}=1, \mathrm{p}=7.3 \times 10^{-233} * \\
\text { Damaged flowers: } \chi^{2}=1,322.9, \mathrm{df}=1, \mathrm{p}=7.3 \times 10^{-289} *\end{array}$} & \multicolumn{4}{|c|}{$\begin{array}{l}\text { Fisher exact test }(\mathrm{I} v s . \mathrm{II}) \text { : } \\
\text { Healthy fruits: } \chi^{2}=1,062.6, \mathrm{df}=1, \mathrm{p}=7.3 \times 10^{-233} * \\
\text { Damaged fruits: } \chi^{2}=1,322.9, \mathrm{df}=1, \mathrm{p}=7.3 \times 10^{-289} *\end{array}$} \\
\hline
\end{tabular}

\begin{tabular}{|c|c|c|c|c|}
\hline \multicolumn{5}{|c|}{ Pairwise compairisons of damaged plant organs } \\
\hline Comparison & A. Stems: $\alpha^{\prime}(p$-value) & Leaves: $\alpha^{\prime}$ (p-value) & \multicolumn{2}{|c|}{ Flower buds and flowers: $\alpha^{\prime}$ (p-value) } \\
\hline St2 vs. St3 & $0.025\left(9.0 \times 10^{-9}\right) *$ & $0.025\left(6.4 \times 10^{-64}\right) *$ & \multicolumn{2}{|c|}{$0.025\left(2.9 \times 10^{-63}\right) *$} \\
\hline St 2 vs. St 4 & $0.050\left(4.0 \times 10^{-31}\right) *$ & $0.017\left(2.3 \times 10^{-33}\right) *$ & \multicolumn{2}{|c|}{$0.050\left(1.4 \times 10^{-115}\right) *$} \\
\hline St 3 vs. St 4 & $0.017\left(2.4 \times 10^{-7}\right) *$ & $0.050(\mathrm{p}<0.001) *$ & \multicolumn{2}{|c|}{$0.017\left(9.4 \times 10^{-16}\right) *$} \\
\hline \multicolumn{5}{|c|}{ E. Damaged fruits } \\
\hline & Cat1 (\%) & Cat2 (\%) & Cat3 (\%) & Global (\%) \\
\hline I & $426(19.7)$ & $225(10.3)$ & $158(7.3)$ & $809(37.3)$ \\
\hline II & $637(29.4)$ & $285(13.2)$ & $435(20.1)$ & $1,357(62.7)$ \\
\hline Global & $1,063(49.1)$ & $510(23.5)$ & $593(27.4)$ & $2,166(100.0)$ \\
\hline I vs. II & $\chi^{2}=84.24, \mathrm{p}=6.3 \times 10^{-20} *$ & $\chi^{2}=14.12, \mathrm{p}=2.2 \times 10^{-4} *$ & $\chi^{2}=268.6, p=$ & \\
\hline
\end{tabular}

I to II, St2 to St 4 see table 1, Cat1: Category 1 fruits, Cat2: Category 2 fruits, Cat3: Category 3 fruits, -: not registered, $\alpha^{\prime}$ : Bonferroni adjusted significance level, *: significant difference.

The availability of Salanaceae wild species in the vicity of eggplant plots would represent a microhabitat favourable to the propagation of this pest insect. The damage caused by Lepidoptera is greater on fruits with an attack rate of $38.7 \%$. This is explained by the fact that at the fruiting stage, the eggplant plant emits volatile compounds which attract fruit borer insects such as Le. orbonalis. In Ivory-Coast, the leaves were more attacked than other organs of the eggplant plants [1]. The differences observed could be explained by the study periods with the high frequency of heavy rains which wash the insecticides; the misuse of pesticides by poorly educated farmers, the attacks in the field by insects varying considerably according to the phenological stage of the plant.

Our study is the first step in evaluating impact of native 
and non-native species on the insect assemblage of eggplant plants cultivated in Balessing (West-Cameroon) especialy when chemical treatments were stopped. The cultivated eggplant plots showed two weeks later after stopping the pesticide treatment, a relatively low abundance and number of insect species with the high representation of non-native pest species. Similar results are reported in ground-dwelling ant communities in anthropized environments [90, 103-105]. The recent report by Dzokou et al. and Ngamaleu-Siewe et al. $[24,91]$ shows that the same recorded orders and families damage chili pepper plants (Piper nigrum L.) in the locality of Penja-Cameroon and potato plants in Balessing-Cameroon. The low diversity of the insect pests is associated with low abundance in native species (nine species i.e. $40.9 \%$ of the total species richness and $29.5 \%$ of the total insect abundance), resulting in the weak exploitation of resources. The exploitation of both food and nest sites was mostly achieved by non-native species (13 non native species i.e. $59.1 \%$ of the species richness and $59.1 \%$ of the total abundance). The high abundance level of the invasive alien species in their introduced range is well known [105]. The low insect species diversity recorded reflects the negative effect of the chemical treatments or the presence of both four native pest species [D. volkeri (Hemiptera: Pyrrhocoridae), La. villosa (Coleoptera: Tenebrionidae), Sp. annulus (Hemiptera: Scutelleridae) and T. ferruginea (Orthoptera: Pyrgomorphidae)] and the five non-native pest species $[E$. rufomarginata (Hemiptera: Pentatomidae), G. acuteangularis (Hemiptera: Coreidae), Le. orbonalis (Lepidoptera: Crambidae), Lp. occidentalis (Hemiptera: Coreidae) and Ma. sexta (Lepidoptera: Sphingidae)].

The recorded native species are frequently reported as field pests on several plant species: D. volkeri (Hemiptera: Pyrrhocoridae) damage cotton Gossypium sp. in west-Africa [59], La. villosa (Coleoptera: Tenebrionidae) damage vegetable crops and nowadays extends its range of action to Europe [106], Sp. annulus (Hemiptera: Scutelleridae) feeds on a variety of wild and cultivated plants species in Zambia [107], T. ferruginea (Orthoptera: Pyrgomorphidae) is a pest of cultivated plants and woody plant species in West and Central Africa [80]. They are also known as pest on eggplant So. aethiopicum Linné, 1756 [1, 101].

Alien species damage cultivated plants not only in their native range but also in areas of introduction. This is the case of the Neotropical native Pentatomidae E. rufomarginata (Hemiptera) in the Brazilian savanna where it causes direct and indirect damage to important crop plants especially Caryocar brasiliense (Caryocaraceae) [108]. The Palaeartic and Neotropical distributed Coreidae G. acuteangularis (Hemiptera), has been found in Albania on various host plants including Cistus sp. (Cistaceae), Quercus sp. (Fagaceae), Pistacia sp. (Anacardiaceae), Daphne sp. (Thymelaeaceae), Phlomis sp. and Lavandula sp. (Lamiaceae) and Arbutus sp. (Ericaceae) [109]. The Indomalaisia and Australia origin Crambidae Le. orbonalis (Lepidoptera) causes heavy yield loss in agricultural, ornamental and horticultural crops [91, 102]. The Neartic origin Coreidae Lp. occidentalis (Hemiptera) and
Sphingidae Ma. sexta (Lepidoptera) damage crops in several countries [77, 79, 84, 85].

Several sap-feeding pests (vectors of plant viruses) are highly polyphagous and have developed resistance to several insecticides in several countries. Transfer of sap-feeding species from neighbouring fallows to cultivated eggplant plots may be the work of gound-dwelling and arborealforaging ant species, as is the case after stopping applications of insecticides in citrus orchards in Cameroon [102]. Based on the reports concerning the harmful activity of exotic species in the localities of introduction, they would carry out a similar activity in eggplant plots in Balessing. Our results showed a low occurrence level of the native pest species, in the presence of the non-native species generally considered as among the most ecologically destructive in cultivated areas where they have been introduced. The low representation of native species could be the result either of the regulation of their populations by local natural enemies, or of a negative force of introduced species. World-wide, synthetic pesticides are commonly used for pest control. But in Australia, India, United States of America and Thailand, inappropriate use of synthetic pesticides against $H$. armigera, Le. orbonalis and other pest insects has resulted in many unwanted effects such as environmental pollution, non-target effect and human health hazards and the development of resistance to almost all classes of insecticides [17, 20, 33, 110]. A similar situation would arise in Balessing locality if the phytosanitary authorities do not take adequate measures to educate gardeners and thus protect the environment and populations. In Balessing (West-Cameroon), the insect species richness in eggplant fields, recorded two weeks after stopping synthetic pesticide applications, is lower than results reported in olericulture crops in Pakistan were 389 specimens, 10 orders, 33 families and 59 species were noted in spinach fields Spinacia oleracea L. (Amaranthaceae), 327 specimens, nine orders, 30 families and 55 species where recorded in fenugreek fields Trigonella foenum-graecum (Fabaceae), 373 specimens related to 11 orders, 34 families and 61 species were recorded in turnip fields Brassica rapa var. rapa L. (Brassicaceae) [12, 111]. Our results are superior to those recorded in Ghana in tomato crops where 14 insect species belonging to 14 families were recorded [28]. These insects pose a threat to potato plants as well as other vegetable crops. In fact, in Sudan, 28 pest species that damage untreated eggplant fields were divided into 18 phytophagous species, seven species that destroy flowers and fruits; three stem borer species. Similarly in Bangladesh, the 20 insect species that damage eggplant plants are divided into 15 phytophagous species, three pest species of flowers and fruits and two boring species of stems and roots [30]. Sap-feeding pest species D. volkeri (Hemiptera: Pyrrhocoridae, 7.7\%), E. rufomarginata (Hemiptera: Pentatomidae, 3.2\%) and $G$. acuteangularis (Hemiptera: Coreidae, 5.8\%), were highly abundant and the most destructive on flowers, leaves and stems. This result is contrary to that of Srinivasan $[12,112]$ who reported the dominance of Lepidoptera in plots of eggplant crops in Taiwan. The presence of Le. orbonalis 
(Lepidoptera: Crambidae) in the field suggests a negative impact on the stems and fruits, as is the case in eggplant plantations in Taiwan [12]. The availability of wild Solanaceae plant species in neighbouring fallows would represent a microhabitat favourable to the propagation of the pest insects. Based on 33,772 damaged organs, leaves were more damaged ( $80.8 \%$ of attacked organs) precisely leaves of St4 plants (St2 plants: 5.9\%; St3 plants: $8.6 \%$; St4 plants: $66.3 \%$ ), than other plant organs (stems: $2.2 \%$, flowers: $10.6 \%$, fruits: $6.4 \%$ ). Indeed at the fruiting phase, leaves, flowers and fruits of St4 plants, emits volatile compounds that attract insects including phytophagous and nectar suckers [1].

\subsection{Community Structure Model}

Insects from St2 and St3 plants and native species community best fitted the BS model which describes nonlinear relationship between abundance and ranks of species and characterizes a stand in which species share an important resource of the environment. Insects from St4 plants, well-maintained and unmaintained plots, alien species and the pooled data exhibited Z model. The Zipf's law is nowadays frequently applied to insect communities SADs $[34,94,113]$. For the $\mathrm{Z}$ model the frequency of each species is inversely proportional to its rank and the model describes an order of appearance of species according to their decreasing requirement to environmental conditions. An ubiquitous species will appear very early and be abundant, while a specialized species will appear later, when the first species have modified the environment, and in small numbers. $\mathrm{Z}$ model is frequently fitted by communities from natural environments, suggesting evolved ecosystems where multispecies networked structure corresponds to an optimal structure for the circulation of information carried out on spatio-temporal scales [94, 95, 114]. Then insects associated with eggplant plants in Balessing, showed a complex network of information closed to that from evolved environments and then presented a fairly significant regeneration force compared to disturbed urban environments

\section{Conclusion}

The purpose of this study in Balessing was to determine the biodiversity of insects associated with eggplant plants and characterize damages on aerial plant organs. Collected specimens of insects associated with eggplant plants belonged to four orders, 14 families, 22 genera and 23 species. Pooled data showed low species richness with the richness ratio closed to zero. Among the plant development stages, St 4 plants showed a very high species richness while it was the contrary in St2 and St3 plants. Unmaintained plots and non-native species showed a high species richness while it was the contrary in well-maintained plots and in native species. Based on the species richness, the pooled data showed that Lepidoptera was highly represented (38.7\%) while Hemiptera and Orthoptera were represented respectively by $34.7 \%$ and $14.1 \%$ and lastly Coleoptera showed the low species richness (12.1\%). Based on the species abundance, Coleoptera was highly represented (46.2\%), followed by Hemiptera $(30.8 \%)$, Lepidoptera $(15.4 \%)$ and lastly Orthoptera $(7.7 \%)$. The overall low diversity of the insect pests is associated with the overall low abundance in native species (nine species i.e. $40.9 \%$ of the total species richness and $29.5 \%$ of the total insect abundance), resulting in the weak exploitation of resources. The exploitation of both food and nest sites was mostly achieved by non-native species (13 alien species i.e. $59.1 \%$ of the species richness and $59.1 \%$ of the total abundance). In Balessing locality, amongst the recorded insect pests associated with eggplant plants, four Afrotropical native species were recorded $[D$. volkeri (Hemiptera: Pyrrhocoridae), La. villosa (Coleoptera: Tenebrionidae), Sp. annulus (Hemiptera: Scutelleridae) and T. ferruginea (Orthoptera: Pyrgomorphidae)] and five alien species were recorded [E. rufomarginata (Hemiptera: Pentatomidae), G. acuteangularis (Hemiptera: Coreidae), Le. orbonalis (Lepidoptera: Crambidae), Lp. occidentalis (Hemiptera: Coreidae) and Ma. sexta (Lepidoptera: Sphingidae)]. Despite chemical treatments, all development stages of Solanum aethiopicum Linnaeus, 1756 plants are damaged in the field mostly by alien pest insects. High percentages of destroyed aerial plant organs were recorded.

The community structure of insects associated with eggplant plants in Balessing, presented a fairly significant regeneration force compared to disturbed urban environments. In this locality of the country, all the conditions combine to soar. Due to the numerical and behavioural dominance of alien insects, a significant number of resources are potentially exploitable. In due course, once the invaders would completely monopolize available resources and saturate the locality, they would not allow native species the niche opportunities to re-establish themselves. The consequences of loosing these native species, which may well interact with the endemic flora, will be of extreme concern. The high occurrence of pests necessitates the reaction of the national phytosanitary control service to reduce economic losses.

\section{Acknowledgements}

The authors acknowledge the Cameroonian Ministry of Higher Education for providing funds through the research support program. They thank the farmers of Balessing for their hospitality.

\section{References}

[1] Johnson, F., Gbon, G. A., Boga, J. P., \& N'Goran, A. (2019). Incidence des insectes et des nématodes sur la production de l'aubergine Solanum aethiopicum Linné, 1756. Variété Djamba F1 dans la zone périurbaine d'Abidjan, Côte d'Ivoire. Int. J. Multidiscip., 6: 6-11.

[2] Schippers, R. R. (2000). African Indigenous Vegetables: An Overview of the Cultivated Species. Natural Resources Institute/ACP-EU Technical Centre for Agricultural and Rural Cooperation, Chatham, UK, Pp. 214. 
[3] Daunay, M. C., \& Hazra, P. (2012). Eggplant, Pp. 257-322. In K. V. Peter \& P. Hazra (eds.), Handbook of Vegetables. TX: Studium Press, Houston.

[4] Lester, R. N., Hakiza, J. J. H., Stavropoulos, N., \& Teixiera M. M. (1986). Variation patterns in the African Scarlet Eggplant, Solanum aethiopicum L, Pp. 283-307. In B. Styles (ed.), Intraspecific classification of wild and cultivated plants. Oxford University Press, Oxford.

[5] Daunay, M. C., Lester, R. N., \& Ano, G. (1997). Les aubergines cultivées, Pp. 83-108. In A. Charrier, M. Jacquot, S. Hamon \& D. Nicolas (eds.), L'Amélioration des plantes tropicales. CIRAD-ORSTOM, Montpellier.

[6] FAO (2021). Fruits et légumes - éléments essentiels de ton alimentation. Année internationale des fruits et des légumes, 2021. Note d'information. Rome (Italy), Pp. 86.

[7] FAO (2008). Vegetable production in the arid and semi-arid conditions in tropical Africa. FAO study on crop production and plant protection. Food and Agricultural Organization, Rome (Italy), Pp. 443.

[8] Mahmoud, H. A. F. (2000). Effect of sulphur and phosphorus on some eggplant cultivars under calcareous soil conditions. Bull. Fac. Agr. Cairo Univ., 51 (2): 209-225.

[9] Zenia, M., \& Halina, B. (2008). Content of microelements in eggplant fruits depending on nitrogen fertilization and plant training method. J. Elem., 13 (2): 269-274.

[10] El-Nemr, M. A., EL-Desuki, M., Fawzy, Z. F. \& El-Bassiony, A. M. (2012). Yield and fruit quality of eggplant as affected by NPK-sources and micronutrient application. J. Appl. Sci. Res., 8 (3): 1351-1357.

[11] Harish, B. N., Babu, P. A., Mahesh, T. \& Venkatesh, Y. P. (2008). A cross-sectional study on the prevalence of food allergy to eggplant. Clin. Exp. Allergy, 22-34.

[12] Srinivasan, R. (2009). Insect and mite pests on eggplant: a field guide for identification and management. AVRDC - The World Vegetable Center, Shanhua, Taiwan, Pp. 64.

[13] Taher D, Solberg S. Ø., Prohens J., Chou Y., Rakha, M., \& Wu T. (2017). World Vegetable Center Eggplant Collection: Origin, Composition, Seed Dissemination and Utilization in Breeding. Front. Plant Sci. 8: 1484.

[14] Asongwe, G. A., Yerima, B. P. K. \& Tening, A. S. (2014). Vegetable production and the livelihood of farmers in Bamenda municipality, Cameroon. Int. J. Curr. Microbiol. Appli. Sc. 3 (12): 682-700.

[15] Basha, K., Ewang, P. N., \& Ndemo, Okoyo, E. (2017). Factors Affecting productivity of Smallholder potato Growers in Bore District, Guji Zone, Oromia Regional State, Ethiopia. Dev. Ctry. Stud., 7 (9): 18-26.

[16] Ngameni, Tchamadeu, N., Kenko, Nkontcheu, D. B., \& Djomo, Nana, E. (2017). Evaluation des facteurs de risques environnementaux liés à la mauvaise utilisation des pesticides par les maraîchers au Cameroun: le cas de Balessing à l'Ouest Cameroun. Afr. Sci., 13 (1): 91-100.

[17] Mengui, K. C., Oh, S., \& Lee, S. H. (2019). The Technical Efficiency of Smallholder Irish Potato Producers in Santa Subdivision, Cameroon. Agriculture, 9 (12): 259.

[18] Daunay, M.-C., \& Dalmasso, A. (1985). Multiplication de
Meloidogyne javanica, M. incognita et M. arenaria sur divers Solarium. Rev. Hematol., 8 (1): 31-34.

[19] Rotino, G. L., Perri, E., Acciarri, N., Sunseri, F., \& Arpaia, S. (1997). Development of eggplant varietal resistance to insects and diseases via plant breeding. Adv. Hortic. Sci, 11 (4): 193-201.

[20] Sridhar, J., Kumari, N., Venkateswarlu, V., Bhatnagar, A., Malik, K., Sharma, S., \& Chakrabarti, S. (2020). Macrosiphum euphorbiae: A new aphid vector (Aphididae: Hemiptera) of PVY o and PLRV on potato from north western hills of India. J. Entomol. Zool. Stud., 8 (2): 1341-1344.

[21] Medakker, A., \& Vijayaraghavan, V. (2007). Successful commercialization of insect-resistant eggplant by a publicprivate partnership: reaching and benefiting resource-poor farmers, Pp. 1829-1831. In A. Krattiger, R. T. Mahoney, L. Nelsen, J. A. Thomson, A. B. Bennett, K. Satyanarayana, G. D. Graff, C. Fernandez \& S. P. Kowalski, (eds.), Intellectual Property Management in Health and Agricultural Innovation: A Handbook of Best Practices, Volume 1 and 2. Oxford: MIHR and Davis, Oxford.

[22] Obodji, A., Aboua, L. R. N., Tano, D. K. C., \& Seri-Kouassi, B. P. (2016). Inventory of entomofaune associated with African eggplant (Solanum aethiopicum L.) according to the phonological stages assessment of damages caused by insect pests. J. Adv. Stud. Agric. Biol. Environ. Sci., 3 (2): 2455-0221.

[23] Dzokou, V. J., Lontchi, Fofe, N., Kamgaing, Kouam, B. H., Yaouba, A., \& Tamesse, J. L. (2021). Fauna Pests Infesting Pepper (Piper nigrum L.) in Penja-Cameroon. Am. J. Entomol., 5 (2): $32-38$.

[24] Maniania, N. K., Ekesi, S., Löhr, B., \& Mwangi, F. (2001). Prospects for biological control of the western flower thrips, Frankliniella occidentalis, with the entomopathogenic fungus, Metarhizium anisopliae, on chrysanthemum. Mycopathologia 155: 229-235.

[25] Cook, D., Herbert, A., Akin, D. S., \& Reed J. (2011). Biology, Crop Injury, and Management of Thrips (Thysanoptera: Thripidae) Infesting Cotton Seedlings in the United States. J. Integr. Pest Manag., 2 (2): 1-9.

[26] Babar, H. C., Asif, H. C., Abdul, G. L., Aslam, B., Imtaiz, A. N., Ammara, R., Fida, H. M., Mehroz, K., Farukh, A., \& Zehua, Z. (2019). Insect Biodiversity in Brinjal AgroEcosystem. Pak. J. Sci. Ind. Res. A: Phys. Sci., 62B (3): 199205.

[27] Ofori, E. S. K., Afful, N., Quartey, E. K., Osae, M., \& Amoatey, H. M. (2015). Preliminary Ecological Studies of Insect Species Associated with Different Accessions of Eggplant (Solanum melongena L.) in Southern Ghana. J. Agric. Ecol., 4 (4): 199-210.

[28] Akunne, C. E., Ononye, B. U., \& Mogbo, T. C. (2013). Insects: Friends or Enemies?. Glob. J. Biol. Agric. Health Sci., 2 (3): 134-140.

[29] Latif, M. A., Rahman, M. M., Islam, M. R., \& Nuruddin, M. M. (2009). Survey of Arthropod Biodiversity in the Brinjal Field. J. Entomol., 6 (1): 28-34.

[30] Alam, M. Z., Crump, A. R., Haque, M. M., Islam, M. S., Hossain, E., Hasan, S. B., Hasan, S. B., \& Hossain, M. S. (2016) Effects of Integrated Pest Management on Pest Damage and Yield Components in a Rice Agro-Ecosystem in the Barisal Region of Bangladesh. Front. Environ. Sci., 4: 22. 
[31] Fontem, D. A., Songwalang, A. T., Berinyuy, J. E., \& Schippers, R. R. (2003). Impact of fungicide applications for late blight management on huckleberry yields in Cameroon. Afr. Crop Sci. J., 11 (3): 163-170.

[32] Sonchieu, J., Ngassoum, M. B., Nantia Akono, E., \& Laxman, P. S. (2018). Pesticide Applications on Some Vegetables Cultivated and Health Implications in Santa, North WestCameroon. SSRG Int. J. Agric. Env., 4 (2): 39-46.

[33] Abossolo, S. A., Batha, R. A. S., \& Djeugang, A. B. (2015). Identification des risques pluviométriques sur la culture du maïs dans l'arrondissement de Penka-Michel, dans les hautes terres de l'Ouest du Cameroun. Afr. Sci., 11 (2): 136-146.

[34] Ngamaleu-Siewe, B., Fouelifack-Nintidem, B., YetchomFondjo, J. A., Moumite Mohamed, B., Tsekane, S. J., Kenne, E. L., Biawa-Kagmegni, M., Tuekam Kowa, P. S., Fantio, R. M., Yomon, A. K. \& Kenne, M. (2021). Abundance and diversity of insects associated with Solanum tuberosum L. 1753 (Solanaceae) after insecticide treatments in Balessing (West-Cameroon). Am. J. Entomol., 5 (3): 51-69.

[35] Kottek, M., Grieser, J., Beck, C., Rudolf, B., \& Rubel F. (2006). World Map of the Köppen-Geiger climate classification updated. Meteorol. Z., 15 (3): 259-263.

[36] Tsalefac, M., Ngoufo, R., Nkwambi, W., Djoumessi, Tatsangue, E., \& Lengue Fobissie, B. (2003). Fréquences et quantités des précipitations journalières sur le territoire camerounais. Publ. Assoc. Intern. Climatol., 15: 359-367.

[37] JESBAD (2013). Connaître Balessing. Jeunesse Estudiantine et Scolaire Balessing de Douala (Cameroun), Pp. 69.

[38] Climate-Data.org. 2020. West climat. Dschang and Bafoussam. https://fr.climate-data.org/afrique/cameroon/west1367/. Accessed on 10th September 2020.

[39] MINADER (2019). Liste des pesticides homologués au Cameroun au 18 Avril 2019. Liste réservée au grand public. Ministère de l'Agriculture et de Développement Rural. Commission Nationale d'Homologation des Produits Phytosanitaires et de Certification des Appareils de Traitement (CNHPPCZT), Yaoundé, Cameroun, Pp. 212.

[40] Delvare, G., \& Aberlenc, H. P. (1989). Les Insectes d'Afrique et d'Amérique Tropicale. Clés pour la reconnaissance des familles. CIRAD. Laboratoire de Faunistique. Acridologie Opérationnelle. Montpellier, France, Pp. 302.

[41] Michel, C. (1991). La grande encyclopédie des insectes. Librairie Griind, Paris, Pp. 511.

[42] Poutouli, W., Silvie, P. \& Aberlenc, H. P. (2011). Hétéroptères phytophages et prédateurs d'Afrique de l'Ouest. Edition Quae; CTA, Versailles (Paris), Pp. 80.

[43] Gourmel, C. (2014). Catalogue illustré des principaux insectes ravageurs et auxiliaires des cultures de Guyane. Coopérative BioSavane, Guyane, Pp. 77.

[44] Moré, M., Kitching, I. J., Cocucci, A. A., Roig-Junent, S., Claps, L. E., \& Morrone, J. J. (2014). Lepidoptera: Sphingidae, Pp. 281-295. In S. Roig-Juñent, L. E. Claps \& J. J. Morrone (eds.), Biodiversidad \& Argentinos (volumen 4), Artrópodos, Universidad Nacional de Tucumán. Facultad de Ciencias Naturales.

[45] Mally, R., Korycinska, A., Agassiz, D. J. L., Hall, J., Hodgetts, J., \& Nuss, M. (2015). Discovery of an unknown diversity of Leucinodes species damaging Solanaceae fruits in sub-
Saharan Africa and moving in trade (Insecta, Lepidoptera, Pyraloidea). Zookeys, 472: 117-162.

[46] Kitching, I. J. (2020). Sphingidae Taxonomic Inventory. http://sphingidae.myspecies.info/. Consulted on 28 September 2020.

[47] Lindrothy, C. H. (1974). Handbooks for the identification of British Insects. Volume 4. Part 2. Coleoptera: Carabidae. Royal Entomological Society, London.

[48] Makarov, K. V. (1994). A key to the genera of the groundbeetle larvae (Coleoptera, Carabidae) of the Palaearctic region. Boll. Mus. reg. Sci. nat. Torino, 12 (1): 221-254

[49] Evans, A. V. (2014). Beetles of Eastern North America. Princeton University Press. Princeton, New Jersey, Pp. 560.

[50] Zettler, J. A., Mateer, S. C., Link-Pérez, M. A., Bailey, J., Demars, G., \& Ness, T. (2016). To Key or Not to Key: A New Key to Simplify \& Improve the Accuracy of Insect Identification. Am. Biol. Teach., 78 (8): 626-633.

[51] Micó, E., \& Galante, E. (2003). Larval morphology and biology of four Netocia and Potosia species (Coleóptera: Scarabaeoidea: Cetoniidae: Cetoniinae). Eur. J. Entomol., 100 (1): $131-142$

[52] Baselga A. S \& Novoa, F. (2005). The Western Palaearctic Neocrepidodera (Coleoptera: Chrysomelidae) of the $N$. impressa and N. ferruginea Species Groups. Ann. Entomol. Soc. Am., 98 (6): 896-907.

[53] Borowiec, L. (2007). Two new species of Charidotella Weise (Coleoptera: Chrysomelidae: Cassidinae: Cassidini), with a key to Charidotella sexpunctata group. Zootaxa, 1586: 59-66.

[54] Tronquet, M. (2014). Catalogue des Coléoptères de France. Association Roussillonnaise d'Entomologie, Perpignan. Supplément au Tome XXIII-R. A. R. E., Pp. 1052.

[55] MNHN \& OFB (2021). Fiche de Stenosis sardoa (Küster, 1848). Inventaire national du patrimoine naturel (INPN), https://inpn.mnhn.fr/espece/cd_nom/244600. Accessed on 23rd August 2021.

[56] Freeman, P., \& Lane, R. P. (1985). Bibionid and Scatopsid flies. Diptera; Bibionidae and Scatopsidae (Handbooks for the Identification of British Insects 9/7). Royal Entomological Society, London, UK, Pp. 74.

[57] Albrecht, A. C. (2017). Illustrated identification guide to the Nordic aphids feeding on Conifers (Pinophyta) (Insecta, Hemiptera, Sternorhyncha, Aphidomorpha). Eur. J. Taxon., 338: $1-160$.

[58] Couilloud, R. (1989). Hétéroptères déprédateurs du cotonnier en Afrique et à Madagascar (Pyrrhocoridae, Pentatomidae, Coreidae, Alydidae, Rhopalidae, Lygaeidae). Cot. Fib. Trop., 44 (3): 185-226.

[59] Perez-Gelabert, D. E., \& Thomas, D. B. (2005). Stink Bugs (Heteroptera: Pentatomidae) of the Island of Hispaniola, with seven new species from the Dominican Republic. Bol. SEA, 37: $319-352$.

[60] Brailovsky, H. (2014). Illustrated key for identification of the species included in the genus Leptoglossus (Hemiptera: Heteroptera: Coreidae: Coreini: Anisoscelini), and descriptions of five new species and new synonyms. Zootaxa, 3794 (3): 143-178. 
[61] Brailovsky, H., \& van, der, Heyden, T. (2019). New distributional notes and key to the known species of Leptoglossus Guérin-Méneville from Guatemala (Heteroptera: Coreidae: Coreinae: Anisoscelini). Rev. Chil. Entomol., 45 (1): 175-180.

[62] Packauskas, R. (1994). Key to the subfamilies and tribes of the New World Coreidae (Hemiptera), with a checklist of published keys to genera and species. Proc. Entomol. Soc. Wash., 96. 44-53.

[63] Broza, M., Blondheim, S., \& Nevo, E. (2002). New species of mole crickets of the Gryllotalpa gryllotalpa group (Orthoptera: Gryllotalpidae) from Israel, based on morphology, song recordings, chromosomes and cuticular hydrocarbons, with comments on the distribution of the group in Europe and the Mediterranean region. Syst. Entomol., 23 (2): 125-135.

[64] Lecoq, M. (2010). Taxonomie et systématique des acridiens et principales espèces d'Afrique de l'Ouest. CIRAD, UPR Acridologie, Montpellier, France, Pp. 106.

[65] Popov, G. B., FishpooL, L. D. C., \& Rowell, C. H. F. (2019). A review of the Acridinae s. str. (Orthoptera: Acridoidea: Acrididae) of eastern Africa with taxonomic changes and description of new taxa. J. Orthoptera Res., 28 (1): 37-105.

[66] Riley, E., Clark, S., \& Seeno, T. (2003). Catalog of leaf beetles of America north of Mexico (Coleoptera: Megalopodidae, Orsodacnidae and Chrysomelidae, excluding Bruchinae). Coleopterists Society, Alaska, Canada, USA, Pp. 290.

[67] de Sousa, W. O., Ribeiro-Costa, C. S., \& Rosado-Neto, G. H. (2019). A preliminary overview of the Brazilian Apioninae (Coleoptera: Brentidae) with an illustrated key for genera, and a checklist with distribution information. Biota Neotrop., 19 (4).

[68] Abdel-Dayem M. S., Fad H. H., El-Torkey A. M., Elgharbawy A. A., Aldryhim Y. N., Kondratieff B. C., Al Ansi A. N., \& Aldhafer H. M. (2017). The beetle fauna (Insecta, Coleoptera) of the Rawdhat Khorim National Park, Central Saudi Arabia. ZooKeys, 653: 1-78.

[69] Borowiec, L., \& Świętojańska, J. (2015). Checklist of tortoise beetles (Coleoptera, Chrysomelidae, Cassidinae) from Colombia with new data and description of a new species. ZooKeys, 518: 87-127.

[70] Bukejs, A. (2012). Taxonomical Structure and Biogeography of Leaf-Beetles (Coleoptera: Chrysomelidae S. L.) of the Latvian Fauna. Taxonomical structure and biogeography of leaf-beetles (Coleoptera: Chrysomelidae s. 1.) of the Latvian fauna. Acta Biol. Univ. Daugavp., 12 (3): 25-34.

[71] Cosandey, V., Chittaro Y., \& Sanchez, A. (2017). Liste commentée des Scarabaeoidea (Coleoptera) de Suisse. Alp. Entomol., 1: 57-90.

[72] Ruzzier, E. \& Martínez-Muñoz, C. (2021). First record of the invasive Lagria villosa (Fabricius, 1781) (Coleoptera: Tenebrionidae: Lagriinae) in Europe. Zootaxa, 4908: 147-150.

[73] Soldati F., \& Soldati, L. (2018). Les Stenosini de la faune de France (Coleoptera, Tenebrionidae). Rev. As. Rousil. Entomol., 27 (1): 21-33.

[74] Çerçi, B., \& Özgen, İ. (2021). Contribution to the Knowledge of Heteroptera (Hemiptera) Fauna of Elazı̆ Province with a New Record for the Fauna of Turkey. J. Het. Turk., 3 (1): 5075.
[75] Ferenca R., Tamutis, V., \& Stankuté, R. (2014). Data on new species of true bugs (Hemiptera: Heteroptera) of Lithuanian fauna. New Rare Lith. Ins. Species, 26: 19-25.

[76] EPPO (2010). Leptoglossus occidentalis: an invasive alien species spreading in Europe. EPPO Reporting Service 1: 8-12

[77] Dellapé P. M., Melo, M. C., Montemayor, S. I., Dellapé, G. \& Brailovsky, H. (2015). Terrestrial Heteroptera (Hemiptera) from Moconá Provincial Park (Misiones, Argentina). Check List, 11 (3): 1662. Doi: 10.15560/11.3.1662.

[78] Kawahara, A., Breinholt, J., Ponce, F., Haxaire, J., Xiao, L., Lamarre, G., Rubinoff, D., \& Kitching, I. (2013). Evolution of Manduca sexta hornworms and relatives: Biogeographical analysis reveals an ancestral diversification in Central America. Mol. Phylogenet. Evol., 68: 381-386.

[79] Kessler, A. \& Baldwin, I. (2002). Manduca quinquemaculata's Optimization of Intra-Plant Oviposition to Predation, Food Quality, and Thermal Constraints. Ecology, 83: 2346-2354.

[80] Yetchom-Fondjo, J. A., Kekeunou, S., Kenne, M., Missoup, A. D., \& Sheng-Quan, X. (2020). Diversity, abundance and distribution of grasshopper species (Orthoptera: Acrididea) in three different types of vegetation with different levels of anthropogenic disturbances in the Littoral Region of Cameroon. J. Insect Biodivers., 14 (1): 16-33.

[81] Roy, R. (2003). Les Acridiens du Nimba et de sa région, Pp. 311-391. In M. Lamotte \& R. Roy (eds.), Le peuplement animal du mont Nimba (Guinée, Côte d'Ivoire, Liberia). Mémoires du Muséum national d'Histoire naturelle, Paris, T. 190.

[82] Uberti, A., Smaniotto, M. A., Giacobbo, C. L., Lovatto, M., Lugaresi, A., \& Girardi, G. C. (2017). New insect pest at theculture of peach: Biology of Lagria villosa Fabricius, 1783 (Coleoptera: Tenebrionidae) fed with peach. Sci. Elec. Arch., 10 (5): 72-76.

[83] Kulijer, D., Dautbasic, M., Hrašovec, B., Vesnić, A., Šarić, Š., \& Mujezinović, O. (2017). Leptoglossus occidentalis Heidemann, 1910 (Heteroptera: Coreidae) in Bosnia and Herzegovina - Current distribution and the earliest documented records. Šumarski list. 11-12: 577-582.

[84] Hizal, E., \& Inan, M. (2012). Leptoglossus occidentalis (Heidemann, 1910) Is An Invasive Insect Species. J. For., 14 (21): 56-61.

[85] Dellapé, G., Colpo, K. D., Melo, M. C., Montemaor, S. I., \& Dellapé, P. M. (2018). Biodiversity of Coreoidea and Pentatomidae (Heteroptera) from Atlantic forest protected areas. Insights into their conservation. An. Acad. Bras. Cienc., 90 (1): 109-122.

[86] Mestre, J., \& Chiffaud, J. (2009). Acridiens du Cameroun et de République centrafricaine. Supplément au catalogue et atlas des acridiens d'Afrique de l'Ouest. Édition numérique, Pp. 170.

[87] Hammer, Ø., Harper, D. A. T., \& Ryan, P. D. (2001). PAST: Paleontological Statistics software pakage for education and data analysis. Palaeontol. Electron., 4: 9.

[88] Chao, A., Chadzon, R. L., Colwell, R. K., \& Shen, T.-J. (2005). A new statistical approach for assessing similarity of species composition with incidence and abundance data. Ecol. Lett., 8: 148-159. 
[89] McGill B. J., Etienne R. S., Gray J. S., Alonso D., Anderson M. J., Benecha H. K., Dornelas M., Enquist B. J., Green J. L., He, F., Hurlbet A. H., Magurran A. E., Marquet P. A., Maurer B. A., Ostling A., Soykan C. U., Ugland K. I. \& White E. P. 2007. Species abundance distributions: moving beyond single prediction theories to integration within an ecological framework. Ecol. Lett., 10 (10): 995-1015.

[90] Biawa-Kagmegni, M., Foguieng-Saha, A. D., GuetsopNgouadjie, R. P., Tsekane, S. J., Fouelifack-Nintidem B. Moumite Mohamed, B., Yetchom-Fondjo, J. A., NgamaleuSiewe, B., Kenne, E. L., Tuekam Kowa P. S., Fantio R. M., Yomon, A. K., Mbenoun Masse, P. S., Kenne, M., \& Fomena, A. (2021). Ants community structure in the urban and the city suburbs areas of Douala (Littoral-Cameroon). J. Insect Biodivers., 25 (2): 033-059.

[91] Johnson, J. B., \& Omland, K. S. (2004). Model selection in ecology and evolution. Trends Ecol. Evol., 19 (2): 101-108.

[92] R Core Team, (2018). R: A language and environment for statistical computing. R Foundation for Statistical Computing, Vienna, Austria. Available from http://www.R-project.org/.

[93] Wilson, J. B. (1991). Methods for fitting dominance/diversity curves. J. Veg. Sci., 2 (1): 35-46.

[94] Li, W. (2002). Zipf's Law Everywhere. Glottometrics, 5: 1421.

[95] Ferreira, F. C., \& Petrere-Jr., M. (2008). Comments about some species abundance patterns: classic, neutral, and niche partitioning models. Braz. J. Biol., 68 (4, Suppl.): 1003-1012.

[96] Marquardt D. W. 1963. An algorithm for least-squares estimation of nonlinear parameters. J. Soc. Ind. Appl. Math., $11(2): 431-441$.

[97] Le, D.-H., Pham, C.-K., Nguyen, T. T. T., \& Bui, T. T. (2012) Parameter extraction and optimization using LevenbergMarquardt algorithm, Pp. 434-437. In Proceedings of 2012 IEEE conference. Fourth International Conference on Communications and Electronics (ICCE), Hanoi University of Science and Technology, Hanoi (Vietnam).

[98] Murthy, Z. V. P. (2014). Nonlinear Regression: LevenbergMarquardt Method, Pp. 1-3. In E. Drioli, \& L. Giorno, (eds.), Encyclopedia of Membranes. Springer-Verlag, Berlin, Heidelberg.

[99] Adja, N. A., Danho, M., Alabi, T. A. F., Gnago, A. J., Zimmer, J. Y., Francis, F., Kouassi, P., Baudoin, J. P., \& Zoro Bi, I. A. (2014). Entomofauna associated with African oleaginous cucurbits (Lagenaria siceraria Molina (Standl. 1930) and Citrullus lanatus Thumb (Matsum \& Nakai 1916)) and impact of pests on production. Int. J. Entomol., 50 (3-4): 301-310.

[100] Navasero, M. V. (2015). Insect Pests of Eggplant, Pp. 354-383. In F. M. Dela Cueva, C. B. Pascual, C. M. Bajet \& T. U. Dalisay, (eds.), Pests and Diseases of Economically Important Crops in the Philippines. Pest Management Council of the Philippine, Inc. c/o Crop Protection Cluster, University of the Philippines Los Banos, College, Laguna.
[101]Joda, A. O., Ewete, F. K., \& Pitan, O. O. R. (2014). Evaluation of Damage Induced by Aspavia armigera Fabricius on Different Rice (Oryza sativa Linn.) Varieties. J. Agric. Sci., 6 (11): 30-36.

[102] Bindu, S. P., Pramanik, A., \& Padhi, G. K. (2015). Studies on Biology and physical measurements of shoot and fruit borer (Leucinodes orbonalis Guenee) of Brinjal in West Bengal, India. Glob. J. Biol. Agric. Health Sci., 4 (1): 215-219.

[103] Uno, S., Cotton, J., \& Philpott, S. M. (2010). Diversity, abundance, and species composition of ants in urban green spaces. Urban Ecosyst., 13: 425-441.

[104] Solar, R. R. C., Barlow, J., Andersen, A. N., Schoereder, J. H., Berenguer, E., Ferreira, J. N., \& Gardner, T. A. (2016). Biodiversity consequences of land-use change and forest disturbance in the Amazon: A multi-scale assessment using ant communities. Biol. Conserv., 197: 98-107.

[105] Holway, D. A., Lach, L., Suarez, A. V., Tsutsui, N. D., \& Case, T. J. (2002). The causes and components of ant invasions. Annu. Rev. Ecol. Syst., 33: 181-233.

[106] Ruzzieri, E., \& Martinez-Munoz, C. A. (2021). First record of the invasive Lagria villosa (Fabricius, 1781) (Coleoptera: Tenebrionidae: Lagriinae) in Europe. Zootaxa, 4908 (1): 147150.

[107] van der Heyden, T. (2017). A recent record of Sphaerocoris annulus (Fabricius, 1775) in Zambia (Hemiptera: Heteroptera: Scutelleridae). Heteropteron, 49: 23-25.

[108] Silva, D. P., \& Oliveira, P. S. (2010). Field Biology of Edessa rufomarginata (Hemiptera: Pentatomidae): Phenology, Behavior, and Patterns of Host Plant Use, Environ. Entomol. 39 (6): 1903-1910.

[109] Van der Heyden, T. (2017). First records of Gonocerus insidiator (Fabricius, 1787) (Hemiptera: Heteroptera: Coreidae: Coreinae: Gonocerini) for Albania. Arquivos Entomoloxicos, 18: 131-132.

[110] Shirale, D., Patil, M., \& Parimi, S. (2017). Insecticide resistance in field populations of Leucinodes orbonalis (Lepidoptera: Crambidae) in India. Can. Entomol., 149 (3): 19.

[111] Gelhaus, J. K. (2005). The Crane-Fly Tipula (Tipula) oleracea (Diptera: Tipulidae). Reported From Michigan; A New Pest of Turfgrass in Eastern North America. Gt. Lakes Entomol., 38 (1): 97-99.

[112] Srinivasan, R., \& Alvarez, J. M. (2011). Specialized Host Utilization of Macrosiphum euphorbiae on a Nonnative Weed Host, Solanum sarrachoides, and Competition with Myzus persicae. Environ. Entomol., 40 (2): 350-356.

[113] Galante, E., \& Cartagena, M. C. (1999). Comparison of Mediterranean dung beetles (Coleoptera: Scarabaeoidea) in cattle and rabbit dung. Environ. Entomol., 28 (3): 420-424.

[114] Shea, K., \& Chesson, P. (2002). Community ecology theory as a framework for biological invasions. Trends Ecol. Evol., 17 (4): 170-176. 